\title{
46. EVOLUTION OF ANTARCTIC WATERS DURING THE MAESTRICHTIAN: FORAMINIFER OXYGEN AND CARBON ISOTOPE RATIOS, LEG 113 1
}

\author{
Enriqueta Barrera ${ }^{2}$ and Brian T. Huber ${ }^{3}$
}

\begin{abstract}
Oxygen and carbon isotopic ratios were measured from Maestrichtian benthic and planktonic foraminifer species and bulk carbonate samples from ODP Sites 689 and 690, drilled on the Maud Rise during Leg 113. Careful scanning electron microscope observations reveal that test calcite in some intervals was diagenetically altered, although $\mathrm{Sr} / \mathrm{Ca}$ and isotopic ratios of these tests do not appear to have been modified significantly. Foraminifer $\delta^{18} \mathrm{O}$ values at both sites document a cooling trend during early Maestrichtian time, a rapid drop in water temperatures at the time of the first appearance of Abathomphalus mayaroensis in the high southern latitude regions (about $69.9 \mathrm{Ma}$ ), and lower water temperatures during late Maestrichtian time. $\delta^{13} \mathrm{C}$ values record a depletion in ${ }^{13} \mathrm{C}$ in the latest early Maestrichtian time beginning at about $72.2 \mathrm{Ma}$, just prior to the sharp late Maestrichtian increase in $\delta^{18} \mathrm{O}$ values. These trends are similar to those previously reported for well-preserved benthic foraminifer species from Seymour Island, in the Antarctic Peninsula. Paleotemperature estimates are also comparable to those at Seymour Island and suggest temperate climatic conditions in Antarctica and that bottom waters in the southern South Atlantic region were of Antarctic origin. Benthic and planktonic foraminifer $\delta^{13} \mathrm{C}$ values fluctuate sympathetically and are higher in upper Maestrichtian sediments than in the lower Maestrichtian sequence.
\end{abstract}

\section{INTRODUCTION}

Most of the evidence that has been gathered for the climate of the polar regions during the Late Cretaceous and early Tertiary is qualitative and indicates considerably warmer temperatures than today (Axelrod, 1984; Creber and Chaloner, 1985; Askin, 1988). Quantitative estimates of water temperatures in polar oceans are essential to reconstruct precisely the climate of the high latitudes, global climatic conditions, and the role of polar regions in regulating global climate during the Late Cretaceous. Oxygen and carbon isotopes of well-preserved benthic and planktonic foraminifers can provide these estimates as well as evidence for resolving current controversies regarding the high and/or low latitude origin of bottom waters during most of the early Tertiary and Late Cretaceous. Yet, there are few isotopic studies of high-latitude regions (Buchardt and Weiner, 1981; Barrera et al., 1987) because carbonate fossils are not abundant in polar sediments and those with good preservation are rare.

ODP Leg 113 Holes 689B $\left(64^{\circ} 31^{\prime} \mathrm{S}, 03^{\circ} 06^{\prime} \mathrm{E}\right)$ and $690 \mathrm{C}$ $\left(65^{\circ} 10^{\prime} \mathrm{S}, 01^{\circ} 12^{\prime} \mathrm{E}\right)$ off the Coast of East Antarctica (Fig. 1) recovered a nearly continuous record of Maestrichtian carbonate sedimentation representing the southernmost occurrence of foraminifers of this age in pelagic sediments. In addition to the completeness of the record, the sections have excellent geochronological control provided by the integration of foraminifer and calcareous nannoplankton datum levels (Huber, this volume; Pospichal and Wise, this volume, chapter 30) and geomagnetic polarity events (Hamilton, this volume). We report here the first high-resolution oxygen and carbon isotope records of Maestrichtian age from pelagic sediments in Antarctic waters based on analysis of monospecific benthic and planktonic foraminifer samples from these holes. These data permit us to infer, in

${ }^{1}$ Barker, P. F., Kennett, J. P., et al., 1990. Proc. ODP, Sci. Results, 113: College Station, TX (Ocean Drilling Program).

2 Department of Geological Sciences, University of Michigan, Ann Arbor, MI 48109.

3 Department of Paleobiology, Smithsonian Institution, Washington, DC 20560.

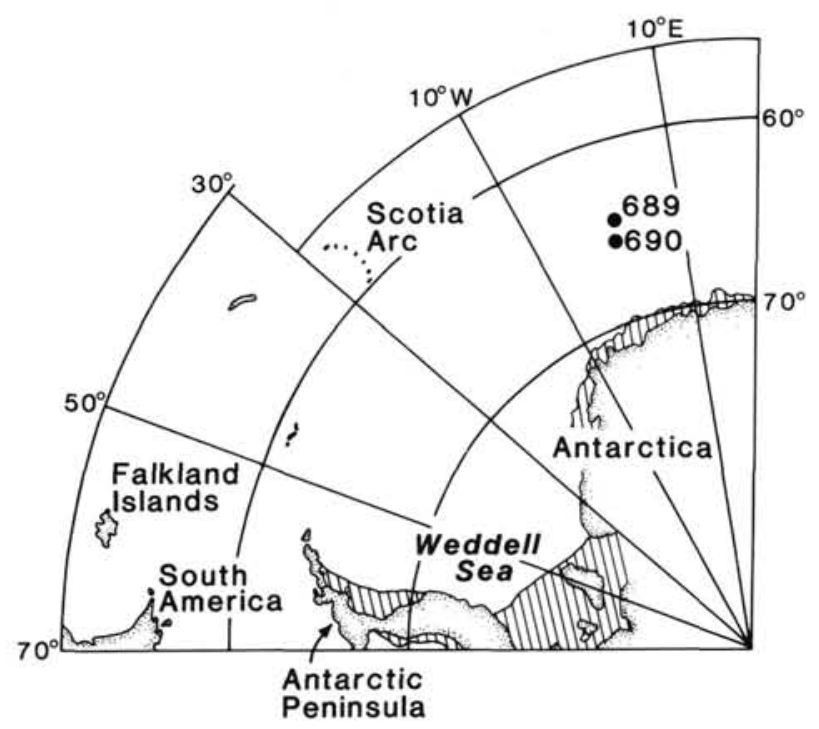

Figure 1. Map showing the location of Sites 689 and 690.

much more detail than hitherto possible, oceanographic and climatic conditions in the southern South Atlantic region during this time. Previous estimates of marine temperatures for Antarctic waters were based on oxygen isotopic ratios of Maestrichtian shallow-water benthic foraminifer taxa from Seymour Island in the Antarctic Peninsula (Barrera et al., 1987), where the isotopic composition of shelf seawater could have varied significantly through time. Age control in this section is not nearly as well resolved as at Maud Rise.

Sites 689 and 690 are located $116 \mathrm{~km}$ apart on the Maud Rise. Sediments at Hole 689B (present water depth of $2080 \mathrm{~m}$ ) were deposited in upper slope depths of 1000-1500 m, whereas those of Hole $690 \mathrm{C}$ (present water depth of $2914 \mathrm{~m}$ ) are from upper bathyal depths at about $1500-2000 \mathrm{~m}$, based on Maestrichtian benthic foraminifers (Thomas, this volume). These sites were located at the same latitude as they are today (Lawver 
et al., 1985). The proximity and the relatively small difference in water depth of the Maud Rise sites should be reflected in the similarity of their isotopic records. This provides an independent means of assessing whether isotopic compositions have been modified by diagenetic alteration, a problem that has plagued foraminifer isotopic reconstructions of Cretaceous climates. In addition, foraminifer preservation has been evaluated by careful scanning electron microscope (SEM) observations, and foraminifer $\mathrm{Sr} / \mathrm{Ca}$ ratios have been measured to estimate the extent to which the chemistry of foraminifer tests has been affected by diagenetic processes.

\section{MATERIALS AND METHODS}

\section{Samples}

Samples from Sites 689 and 690 analyzed in this study are listed in Tables 1 and 2. Foraminifer samples consist of the planktonic species Abathomphalus mayaroensis, Archaeoglobigerina australis, and Globigerinelloides multispinatus, and the benthic taxa Nuttallides truempyi, Gavelinella beccariiformis, and Coryphostoma incrassata. These species were selected based on: (1) their abundance in sediment samples, (2) their stratigraphic range, and (3) the degree to which benthic taxa were cosmopolitan, facilitating comparison of isotopic data from high- and low-latitude locations.

A small portion of unprocessed sediment from each sample was dried and analyzed isotopically. In most cases, over $70 \%$ of the sediment sample was composed of particles smaller than 63 $\mu \mathrm{m}$, which include small foraminifers, coccoliths, and other materials. We refer to these samples as "bulk carbonate."

\section{ANALYTICAL METHODS}

Samples were disaggregated by stirring in water heated to $40^{\circ}-50^{\circ} \mathrm{C}$ and ultrasonically cleaned in tap water before sieving them through a $63 \mu \mathrm{m}$ screen. Planktonic foraminifer samples were picked from the $150-250 \mu \mathrm{m}$ size-fraction. A few benthic foraminifer samples were smaller than $250 \mu \mathrm{m}$. Foraminifer textural preservation was judged by SEM observations of the interior and exterior chamber surfaces and the wall structure of tests. Prior to isotopic analysis and SEM observation, foraminifer tests were fractured with a sharp needle and agitated in dis- tilled water in an ultrasonic bath to remove adhering or infilling fine-grained material. After each rinse the supernatant was pipetted out. Specimens for $\mathrm{Sr}$ and $\mathrm{Ca}$ analyses were also rinsed once with acetone before two final rinses with distilled water.

Isotopic analyses were performed at the stable isotope laboratories of Case Western Reserve University (CWRU), Cleveland, Ohio, and the University of Michigan (UM), Ann Arbor, Michigan. Analyses are reported in $\delta$ notation as per mil deviations from the Peedee Belemnite (PDB) standard. At CWRU, samples were reacted individually with anhydrous phosphoric acid at $25^{\circ} \mathrm{C}$. At UM, samples were reacted in a similar manner at $55^{\circ} \mathrm{C}$ in an on-line gas extraction line coupled to the inlet of a VG602E ratio mass spectrometer. At both laboratories, isotopic measurements were made relative to standard $\mathrm{CO}_{2}$ gases whose compositions are related to PDB values through numerous analyses of National Bureau of Standards standard \#20 (Solnhofen limestone), which is taken to have a $\delta^{18} \mathrm{O}$ value of -4.14 per mil and a $\delta^{13} \mathrm{C}$ value of -1.06 per mil (Craig, 1957). Isotopic values have a precision of 0.05 per mil for $\delta^{13} \mathrm{C}$ and 0.1 for $\delta^{18} \mathrm{O}$. Results from UM are indicated by an asterisk in Tables 1 and 2 . Water temperatures were calculated using the equation of Epstein et al. (1953) and assuming that the oxygen isotopic composition of Maestrichtian oceans was -1 per mil relative to Standard Mean Ocean Water (SMOW).

$\mathrm{Sr}$ and $\mathrm{Ca}$ concentrations were determined from dilutions of foraminifer samples reacted with $0.3 \mathrm{~N} \mathrm{HNO}_{3}$ acid solutions. $\mathrm{Sr}$ was analyzed by graphite furnace atomic absorption spectroscopy (GFAAS) and measurements have a precision of better than $5 \%$ and an accuracy better than $10 \%$ of the amount present. Ca was determined by inductively coupled plasmaatomic emission spectrometry (ICP-AES). Ca analyses have both accuracy and precision of better than $5 \%$ of the amount present. Results are reported as molar $\mathrm{Sr} / \mathrm{Ca}$ ratios.

\section{AGE DETERMINATIONS}

Integration of planktonic foraminifer and calcareous nannoplankton biostratigraphic data (Huber, this volume; Pospichal and Wise, this volume, chapter 30 ) with magnetic polarity data enables assignment of the standard numbered geomagnetic anomaly sequence to the polarity reversal stratigraphy of Sites 689 and 690 . This is correlated with the Haq et al. (1987) time scale.

Table 1. Maestrichtian oxygen and carbon isotope data for selected foraminifer species from Hole 689B.

\begin{tabular}{|c|c|c|c|c|c|c|c|c|c|c|c|c|c|c|c|c|}
\hline & \multirow{2}{*}{$\begin{array}{l}\text { Core, section, } \\
\text { interval }(\mathrm{cm})\end{array}$} & \multirow{2}{*}{$\begin{array}{l}\text { Depth } \\
\text { (mbsf) }\end{array}$} & \multicolumn{2}{|c|}{$\begin{array}{c}\text { Archaeoglobigerina } \\
\text { australis }\end{array}$} & \multicolumn{2}{|c|}{$\begin{array}{l}\text { Globigerinelloides } \\
\text { multispinatus }\end{array}$} & \multicolumn{2}{|c|}{$\begin{array}{c}\text { Abathomphalus } \\
\text { mayaroensis }\end{array}$} & \multicolumn{2}{|c|}{$\begin{array}{c}\text { Nuttallides } \\
\text { truempyi }\end{array}$} & \multicolumn{2}{|c|}{$\begin{array}{l}\text { Gavelinella } \\
\text { beccariiformis }\end{array}$} & \multicolumn{2}{|c|}{$\begin{array}{c}\text { Coryphostoma } \\
\text { incrassata }\end{array}$} & \multicolumn{2}{|c|}{$\begin{array}{l}\text { Bulk } \\
\text { carbonate }\end{array}$} \\
\hline & & & $\delta^{18} \mathrm{O}$ & $\delta^{13} \mathrm{C}$ & $\delta^{18} \mathrm{O}$ & $\delta^{13} \mathrm{C}$ & $\delta^{18} \mathrm{O}$ & $\delta^{13} \mathrm{C}$ & $\delta^{18} \mathrm{O}$ & $\delta^{13} \mathrm{C}$ & $\delta^{18} \mathrm{O}$ & $\delta^{13} \mathrm{C}$ & $\delta^{18} \mathrm{O}$ & $\delta^{13} \mathrm{C}$ & $\delta^{18} \mathrm{O}$ & $\delta^{13} \mathrm{C}$ \\
\hline \multirow{4}{*}{ 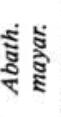 } & $27 X-1,85-89$ & 246.87 & 0.46 & 1.83 & 0.18 & 2.65 & 0.31 & 1.58 & 1.01 & 1.47 & 0.70 & 1.08 & 0.95 & 0.99 & 0.51 & 1.39 \\
\hline & $27 X-2,83-87$ & 248.35 & 0.49 & 2.39 & & & 0.40 & 1.83 & 1.09 & 1.96 & 0.51 & 1.28 & 0.91 & 0.74 & 0.46 & 1.50 \\
\hline & $27 C-3,83-87$ & 249.87 & & & 0.47 & 2.23 & 0.43 & 1.73 & 1.10 & 1.21 & 0.74 & 1.25 & & & 0.36 & 1.44 \\
\hline & $27 \mathrm{X}, \mathrm{CC}$ & 250.10 & 0.55 & 2.18 & & & 0.82 & 5.00 & 1.10 & 1.80 & 0.70 & 1.46 & & & 0.36 & 1.44 \\
\hline \multirow{13}{*}{ 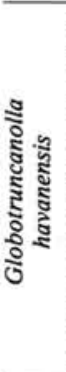 } & $28 X-1,76-80$ & 256.38 & & & 0.92 & 1.83 & 0.4 & 1.18 & 1.26 & 0.80 & 0.85 & 0.39 & & & 0.78 & 0.76 \\
\hline & $28 X-2,80-84$ & 257.92 & 0.09 & 1.40 & 0.37 & 1.19 & & & & & 0.82 & 0.73 & 1.02 & 0.05 & 0.75 & 1.11 \\
\hline & $28 X-3,83-87$ & 259.45 & 0.24 & 1.55 & 0.47 & 1.28 & & & & & 0.59 & 0.22 & 1.12 & -0.04 & 0.62 & 0.70 \\
\hline & $28 X-4,83-87$ & 260.97 & 0.06 & 1.71 & 0.51 & 1.87 & & & & & 0.44 & 0.74 & 0.86 & 0.43 & 0.86 & 1.27 \\
\hline & $28 \mathrm{X}, \mathrm{CC}$ & 261.80 & 0.08 & 1.90 & & & & & & & 0.68 & 0.75 & & & & \\
\hline & $29 X-1,83-87$ & 266.05 & -0.01 & 1.88 & 0.40 & 1.99 & & & & & 0.48 & 0.50 & & & 0.45 & 1.19 \\
\hline & $29 X-2,83-87$ & 267.55 & -0.04 & 1.77 & 0.63 & 2.01 & & & & & 0.45 & 0.79 & 1.02 & 0.62 & 0.55 & 1.00 \\
\hline & $29 X-3,83-87$ & 269.05 & -0.17 & 1.99 & 0.37 & 1.64 & & & & & 0.58 & 0.48 & & & 0.20 & 1.23 \\
\hline & $29 \mathrm{X}, \mathrm{CC}$ & 269.50 & -0.42 & 2.32 & & & & & & & 0.42 & 1.10 & 0.70 & 0.97 & & \\
\hline & $30 X-1,83-85$ & 275.75 & -0.03 & 1.96 & & & & & & & 0.29 & 1.42 & & & 0.41 & 1.40 \\
\hline & $30 X-2,88-92$ & 277.30 & 0.16 & 2.93 & 0.63 & 2.85 & & & & & 0.52 & 1.30 & & & 0.88 & 1.20 \\
\hline & $30 X-3,78-83$ & 278.70 & -0.02 & 1.92 & & & & & & & 0.23 & 1.13 & & & 0.94 & 1.43 \\
\hline & $30 \mathrm{X}, \mathrm{CC}$ & 279.20 & -0.13 & 1.95 & 0.31 & 1.86 & & & & & 0.24 & 0.85 & & & 0.94 & 1.43 \\
\hline \multirow{3}{*}{ லั } & $32 X-1,41-43$ & 291.21 & -0.20 & 1.73 & & & & & & & 0.21 & 1.37 & & & 0.06 & 1.49 \\
\hline & $32 \mathrm{X}, \mathrm{CC}$ & 291.30 & -0.07 & & 0.14 & 1.99 & & & & & 0.12 & 0.98 & & & & \\
\hline & $33 \mathrm{X}, \mathrm{CC}$ & 294.50 & & & -0.05 & 1.85 & & & & & 0.30 & 0.81 & & & & \\
\hline
\end{tabular}

Note: Age determinations for the planktonic foraminifer zones shown on the left are discussed in the text. 
Table 2. Maestrichtian oxygen and carbon isotope data for selected foraminifer species from Hole $690 \mathrm{C}$.

\begin{tabular}{|c|c|c|c|c|c|c|c|c|c|c|c|c|c|c|c|c|}
\hline & \multirow{2}{*}{$\begin{array}{c}\text { Sample } \\
\text { (core, section, } \\
\text { interval) }\end{array}$} & \multirow{2}{*}{$\begin{array}{l}\text { Depth } \\
\text { (mbsf) }\end{array}$} & \multicolumn{2}{|c|}{$\begin{array}{c}\text { Archaeoglobigerina } \\
\text { australis }\end{array}$} & \multicolumn{2}{|c|}{$\begin{array}{c}\text { Globigerinelloides } \\
\text { multispinatus }\end{array}$} & \multicolumn{2}{|c|}{$\begin{array}{c}\text { Abathomphalus } \\
\text { mayaroensis }\end{array}$} & \multicolumn{2}{|c|}{$\begin{array}{l}\text { Nuttallides } \\
\text { truempyi }\end{array}$} & \multicolumn{2}{|c|}{$\begin{array}{c}\text { Gavelinella } \\
\text { beccariiformis }\end{array}$} & \multicolumn{2}{|c|}{$\begin{array}{l}\text { Coryphostoma } \\
\text { incrassata }\end{array}$} & \multicolumn{2}{|c|}{$\begin{array}{c}\text { Bulk } \\
\text { carbonate }\end{array}$} \\
\hline & & & $\delta^{18} \mathrm{O}$ & $\delta^{13} \mathrm{C}$ & $\delta^{18} \mathrm{O}$ & $\delta^{13} \mathrm{C}$ & $\delta^{18} \mathrm{O}$ & $\delta^{13} \mathrm{C}$ & $\delta^{18} \mathrm{O}$ & $\delta^{13} \mathrm{C}$ & $\delta^{18} \mathrm{O}$ & $\delta^{13} \mathrm{C}$ & $\delta^{18} \mathrm{O}$ & $\delta^{13} \mathrm{C}$ & $\delta^{18} \mathrm{O}$ & $\delta^{13} \mathrm{C}$ \\
\hline \multirow{10}{*}{ 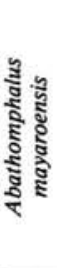 } & $16 \mathrm{X}, \mathrm{CC}$ & 258.00 & & & 0.52 & 2.68 & 0.73 & 2.08 & 1.05 & 1.53 & & & 1.33 & 1.53 & & \\
\hline & $17 X-1,119-123$ & 263.01 & 0.72 & 2.90 & 0.47 & 2.75 & $0.67^{\mathrm{a}}$ & $1.71^{\mathrm{a}}$ & $1.13^{\mathrm{a}}$ & $0.97^{\mathrm{a}}$ & $0.68^{\mathrm{a}}$ & $0.73^{\mathrm{a}}$ & 1.21 & 1.45 & 0.76 & 2.50 \\
\hline & $17 X-3,119-123$ & 265.01 & 0.59 & 2.06 & $0.34^{\mathrm{a}}$ & 2.77 & 0.40 & 1.74 & 1.03 & 1.39 & 0.69 & 1.17 & 1.23 & 1.49 & 0.57 & 2.30 \\
\hline & $17 \mathrm{X}, \mathrm{CC}$ & 266.60 & 0.33 & 2.29 & 0.35 & $2.70^{\mathrm{a}}$ & 0.56 & 1.87 & 1.10 & 2.13 & 0.72 & 1.47 & & & & \\
\hline & $18 X-1,119-123$ & 272.61 & 0.20 & 2.33 & 0.44 & 4.18 & 0.40 & 1.74 & 0.92 & 1.61 & 0.62 & 1.03 & 1.44 & 1.26 & 0.59 & 2.03 \\
\hline & $18 X-2,119-123$ & 274.11 & $0.18^{\mathrm{a}}$ & 2.55 & 0.49 & 2.52 & $0.38^{\mathrm{a}}$ & $1.88^{\mathrm{a}}$ & 0.45 & 1.19 & & & & & 0.39 & 2.32 \\
\hline & $18 X-3,98-102$ & 275.40 & -0.12 & $2.43^{\mathrm{a}}$ & $0.45^{\mathrm{a}}$ & $2.28^{\mathrm{a}}$ & $0.39^{\mathrm{a}}$ & $1.84^{\mathrm{a}}$ & 0.71 & 1.33 & $0.72^{\mathrm{a}}$ & $1.19^{\mathrm{a}}$ & & & 0.58 & 2.08 \\
\hline & $18 X-4,95-99$ & 276.87 & $0.02^{\mathrm{a}}$ & $0.29^{\mathrm{a}}$ & $2.34^{\mathrm{a}}$ & $0.34^{\mathrm{a}}$ & $1.86^{\mathrm{a}}$ & 0.74 & 1.50 & & & & & & 0.87 & 2.02 \\
\hline & $18 \times-5,46-49$ & 277.87 & & & $0.52^{\mathrm{a}}$ & $2.27^{\mathrm{a}}$ & $0.42^{\mathrm{a}}$ & $1.62^{\mathrm{a}}$ & $0.78^{\mathrm{a}}$ & $1.22^{\mathrm{a}}$ & $0.74^{\mathrm{a}}$ & $1.24^{\mathrm{a}}$ & & & 0.57 & 2.28 \\
\hline & $18 \mathrm{X}, \mathrm{CC}$ & 278.30 & $0.27^{b}$ & $1.90^{\mathrm{b}}$ & 0.27 & $1.79^{\mathrm{a}}$ & & & 0.74 & 0.68 & 0.73 & 0.31 & & & & \\
\hline \multirow{22}{*}{ हैं हैं } & $19 X-1,119-123$ & 282.31 & -0.61 & 1.22 & 0.39 & 1.25 & & & 0.79 & 0.22 & 0.28 & -0.02 & & & 0.42 & 1.27 \\
\hline & $19 X-2,119-123$ & 283.81 & & & 0.22 & 1.54 & & & 0.51 & 0.86 & 0.50 & 0.64 & 1.00 & 0.31 & 0.29 & 1.15 \\
\hline & $19 X-3,119-123$ & 285.31 & $-0.49^{\mathrm{a}}$ & $2.02^{\mathrm{a}}$ & & & & & & & $0.39^{\mathrm{a}}$ & $0.56^{\mathrm{a}}$ & & & -0.07 & 1.54 \\
\hline & $19 X-4,119-123$ & 286.81 & $-0.10^{a}$ & $1.75^{\mathrm{a}}$ & $0.19^{\mathrm{a}}$ & $1.74^{\mathrm{a}}$ & & & & & $0.42^{\mathrm{a}}$ & $0.85^{\mathrm{a}}$ & 1.11 & 0.49 & 0.24 & 1.64 \\
\hline & $19 X-5,110-112$ & 288.20 & $-0.42^{\mathrm{a}}$ & $2.14^{\mathrm{a}}$ & $0.23^{\mathrm{a}}$ & $1.83^{\mathrm{a}}$ & & & & & $0.32^{\mathrm{a}}$ & $0.86^{\mathrm{a}}$ & 1.31 & 0.63 & 0.33 & 1.70 \\
\hline & $19 X-6,119-123$ & 289.81 & -0.24 & 1.98 & $0.18^{\mathrm{a}}$ & $1.85^{\mathrm{a}}$ & & & & & & & & & 0.28 & 1.64 \\
\hline & $19 \mathrm{X}, \mathrm{CC}$ & 290.60 & $-0.13^{a}$ & $1.93^{\mathrm{a}}$ & 0.34 & 1.93 & & & & & 0.46 & 0.94 & 1.07 & 0.56 & & \\
\hline & $20 \mathrm{X}-1,118-121$ & 292.00 & -0.43 & 2.16 & 0.26 & 4.61 & & & & & 0.25 & 0.58 & 0.92 & 0.14 & -0.31 & 0.89 \\
\hline & $20 X-2,118-120$ & 293.48 & $-0.05^{\mathrm{a}}$ & $2.11^{\mathrm{a}}$ & $0.27^{\mathrm{a}}$ & $2.09^{\mathrm{a}}$ & & & & & $0.41^{\mathrm{a}}$ & $0.81^{\mathrm{a}}$ & & & 0.16 & 1.44 \\
\hline & $20 \mathrm{X}-3,116-118$ & 294.98 & $-0.14^{\mathrm{a}}$ & $1.90^{\mathrm{a}}$ & $0.16^{\mathrm{a}}$ & $2.00^{\mathrm{a}}$ & & & & & 0.28 & 0.91 & & & 0.26 & 1.42 \\
\hline & $20 \times-4,96-98$ & 296.27 & -0.60 & 2.18 & $0.13^{\mathrm{a}}$ & $2.01^{\mathrm{a}}$ & & & & & 0.22 & 0.51 & 0.69 & 0.33 & -0.12 & 1.27 \\
\hline & $20 X-5,108-110$ & 297.82 & $-0.38^{\mathrm{a}}$ & $2.18^{\mathrm{a}}$ & $0.12^{\mathrm{a}}$ & $1.93^{\mathrm{a}}$ & & & & & $0.50^{\mathrm{a}}$ & $0.68^{\mathrm{a}}$ & & & 0.13 & 1.30 \\
\hline & $20 \mathrm{X}-6,119-123$ & 299.45 & $-0.40^{\mathrm{a}}$ & $2.25^{\mathrm{a}}$ & $0.25^{\mathrm{a}}$ & $2.06^{\mathrm{a}}$ & & & & & $0.21^{\mathrm{a}}$ & $0.54^{\mathrm{a}}$ & & & & \\
\hline & $20 \mathrm{X}, \mathrm{CC}$ & 300.40 & $-0.82^{a}$ & $2.48^{\mathrm{a}}$ & 0.02 & 2.18 & & & & & & & 0.71 & 0.79 & & \\
\hline & $21 X-1,118-122$ & 300.94 & $-1.19^{\mathrm{a}}$ & $2.66^{\mathrm{a}}$ & $-0.24^{\mathrm{a}}$ & $2.15^{\mathrm{a}}$ & & & & & $0.19^{\mathrm{a}}$ & $1.04^{\mathrm{a}}$ & & & -0.21 & 1.42 \\
\hline & $21 X-2,118-122$ & 302.44 & $-0.65^{\mathrm{a}}$ & $1.89^{\mathrm{a}}$ & $-0.33^{\mathrm{a}}$ & $1.99^{\mathrm{a}}$ & & & & & $-0.09^{\mathrm{a}}$ & $0.58^{\mathrm{a}}$ & & & -0.30 & 1.38 \\
\hline & $21 X-3,118-122$ & 303.94 & $-0.82^{b}$ & $2.42^{\mathrm{b}}$ & 0.01 & 5.95 & & & & & 0.11 & 1.35 & & & 0.01 & 1.76 \\
\hline & $21 X-4,118-122$ & 305.44 & $-0.69^{\mathrm{a}}$ & $2.47^{\mathrm{a}}$ & $-0.27^{a}$ & $2.21^{\mathrm{a}}$ & & & & & $-0.04^{a}$ & $1.18^{\mathrm{a}}$ & & & -0.07 & 1.56 \\
\hline & $21 X-5,118-122$ & 306.94 & $-0.59^{\mathrm{a}}$ & $2.34^{\mathrm{a}}$ & & & & & & & 0.15 & 1.17 & & & 0.07 & 1.43 \\
\hline & $21 X, C C$ & 307.80 & $-0.16^{a}$ & $2.31^{\mathrm{a}}$ & & & & & & & 0.20 & 1.29 & & & & \\
\hline & $22 \mathrm{X}-1,118-122$ & 311.62 & $-0.31^{b}$ & $2.27^{b}$ & $-0.21^{\mathrm{a}}$ & $1.99^{\mathrm{a}}$ & & & & & 0.17 & 1.55 & & & -0.20 & 1.41 \\
\hline & $22 X-1,118-122$ & 313.12 & & & & & & & & & 0.17 & 1.55 & & & -0.02 & 1.43 \\
\hline லे & $22 \mathrm{X}-3,107-111$ & 314.52 & $-0.62^{\mathrm{a}}$ & $2.16^{\mathrm{a}}$ & $-0.23^{a}$ & $1.94^{\mathrm{a}}$ & & & & & 0.03 & 0.85 & & & 0.03 & 1.43 \\
\hline ல Е & $22 X-4,118-122$ & 316.62 & & & $-0.15^{\mathrm{a}}$ & $2.00^{\mathrm{a}}$ & & & & & -0.06 & 0.82 & & & 0.01 & 1.62 \\
\hline
\end{tabular}

Note: Age determinations for the planktonic foraminifer zones shown on the left are discussed in the text.

andicates isotopic measurements performed at the University of Michigan.

Indicates average of two samples from the same interval.

Magnetostratigraphic chron boundaries were used as datums to calculate averaged sedimentation rates (see Huber, this volume, Fig. 8), suggesting about $5.18 \mathrm{~m} / \mathrm{m} . \mathrm{y}$. for Hole $689 \mathrm{~B}$ and 9.53 $\mathrm{m} / \mathrm{m}$.y. for Hole $690 \mathrm{C}$. Based on these rates, the lowermost sample analyzed from Hole 689B was deposited at about 75 $\mathrm{Ma}$, and the lowermost sample from Hole $690 \mathrm{C}$ has a slightly younger age at about $74 \mathrm{Ma}$. Although samples of these ages are Campanian (Haq et al., 1987), we refer to them here as early Maestrichtian due to uncertainties in their age assignment (see Pospichal and Wise, this volume, chapter 32). The late/early Maestrichtian boundary is based on first appearance datums of the foraminifer species Abathomphalus mayaroensis and the calcareous nannoplankton species Nephrolitus frequens, both of which first occur at the same level in the middle of Chron $31 \mathrm{R}$ at Holes 689B and 690C.

\section{FORAMINIFER ISOTOPIC SYSTEMATICS}

It is impossible to be certain whether oxygen or carbon isotopic compositions of Maestrichtian species analyzed in this study reflect equilibrium precipitation. Cretaceous planktonic foraminifer taxa are completely different from modern ones, and benthic foraminifer species have modern representatives only at the genus level.

Most Recent benthic foraminifer species characteristic of deep-water environments do not precipitate their tests in either oxygen or carbon isotopic equilibrium with seawater (Woodruff et al., 1980; Belanger et al., 1981). Interspecific differences in oxygen and carbon isotope fractionation of well-preserved benthic foraminifers of Tertiary age appear to remain the same through time, implying that species departure from equilibrium also remains constant (Savin et al., 1981; Shackleton et al., 1984). The isotopic systematics of Coryphostoma incrassata have not been investigated. Based mostly on analysis of Tertiary specimens, Shackleton et al. (1984) estimated that species of Nuttallides and Gavelinella are depleted in ${ }^{18} \mathrm{O}$ by 0.35 and 0.3 per mil, respectively, relative to equilibrium values, although carbon isotopic compositions are in equilibrium. Because the fractionations of these taxa were consistently different from those reported by Shackleton et al., no adjustments have been made to our data in tables or figures.

A "vital effect" appears to influence $\delta^{13} \mathrm{C}$ values of Recent planktonic foraminifer species (Vergnaud Grazzini, 1976; Williams et al., 1977). However, $\delta^{13} \mathrm{C}$ values of several planktonic species are very close to those of total dissolved $\mathrm{CO}_{2}$ in seawater at the depth at which calcification is inferred to have occurred (Williams et al., 1977). The deviation of ${ }^{18} \mathrm{O} /{ }^{16} \mathrm{O}$ ratios of most planktonic foraminifer species from equilibrium values with seawater is apparently small (Williams et al., 1979). If the fractionation of Maestrichtian planktonic taxa is controlled by the same factors influencing that of Recent forms, $\delta^{18} \mathrm{O}$ values should reflect the temperature and isotopic composition of the water in which calcification occurred.

\section{FORAMINIFER PRESERVATION}

Diagenetic processes affecting the isotopic composition of foraminifer calcite in deep-sea sediments commonly include dissolution and reprecipitation of calcite as secondary or replacement calcite. These two processes are usually referred to together under the term "recrystallization." Dissolution and reprecipitation can modify significantly the original isotopic com- 
position of Tertiary and Cretaceous foraminifer calcite (Killingley, 1983). Consequently, we have taken three approaches to estimate the extent to which foraminifer calcite and isotopic ratios from Sites 689 and 690 have been diagenetically altered: (1) SEM observations of tests, (2) comparison of foraminifer and pore water $\mathrm{Sr} / \mathrm{Ca}$ ratios, and (3) examination of the consistency in the isotopic fractionation of taxa.

\section{TEXTURAL PRESERVATION}

Two types of textural alteration are evident in foraminifer calcite from Holes 689B and 690C: (1) encrustation of chamber walls by secondary calcite and (2) replacement of the original calcite of the walls by secondary calcite. The first is readily recognized as euhedral overgrowth crystals on chamber surfaces. The latter can be characterized by the growth of coarser calcite crystals (Neugebauer, 1974, 1975) that are often euhedral (Pl. 1, Fig. 2; Pl. 1, Fig. 3; Pl. 3, Fig. 1; Pl. 3, Fig. 2), instead of the original crystal or crystal units that are less than $0.5 \mu \mathrm{m}$ in size (Towe and Cifelli, 1967), and/or by the presence of blocky secondary calcite within chamber walls (Barrera, 1987). Blocky secondary calcite has a massive appearance and fractures along cleavage surfaces, as observed in G. beccariiformis in Plate 2, Figure 2 and Plate 2, Figure 3.

Interior surfaces of foraminifer tests from all cores from Hole 689B, and Cores 113-690C-17X, 113-690C-18X, and 113$690 \mathrm{C}-22 \mathrm{X}$ and Sample 690-19X-1, 119-123 cm, are encrusted with calcite overgrowth crystals. However, encrustation is minor in samples from the lower part of Core 113-689-28X (Pl. 4, Fig. 4) and from Core 113-689B-29X. Euhedral and/or blocky secondary calcite extensively replaces chamber walls of tests from Hole 689B (Pl. 2, Fig. 2; Pl. 3, Fig. 1; Pl. 3, Fig. 2; Pl. 4, Fig. 1; Pl. 4, Fig. 3; Pl. 4, Fig. 4) and tests from Hole 690C from the levels listed above (Pl. 1, Fig. 2; Pl. 1, Fig. 3; Pl. 1, Fig. 1; Pl. 2, Fig. 4). In samples from Hole $690 \mathrm{C}$, the amount of overgrowth and replacement is greater in those from Core 113-690C-17X and in general decreases with increasing sample depth through Core 113-690C-18X and 113-690C-19X. Specimens from Core 113-690C-22X show somewhat similar preservation as those from the uppermost core.

Overgrowth crystals in planktonic and benthic tests from Samples 113-690C-19X-2, 119-123 cm, to 113-690C-21X-5, 118$122 \mathrm{~cm}$, are small and/or nearly absent (Pl. 1, Fig. 4; Pl. 3, Fig. 4; Pl. 4, Fig. 2). Tests from these levels show excellent preservation when observed under the binocular microscope (Huber, this volume). SEM observations reveal that most of the wall structure of foraminifer tests seems to be composed of finegrained crystals or polycrystalline units. Well-defined pores and layers within the wall of planktonic tests are still present (Pl. 1, Fig. 4; Pl. 3, Fig. 4; Pl. 4, Fig. 2). However, there are also large patches of replacement calcite within the wall of most benthic tests from some of these samples, as illustrated in $G$. beccariiformis from Sample 113-690C-21X-1, 118-122 cm (Pl. 2, Fig. $1)$. These areas are small in planktonic tests.

\section{CHEMICAL PRESERVATION}

The approach most frequently used to estimate the extent of diagenetic alteration of deep-sea sediments from the chemistry of pore waters and solids is based on comparison of $\mathrm{Sr} / \mathrm{Ca}$ ratios of pore waters and carbonate (Baker et al., 1982; Stout, 1985; Baker, 1986). Abiologically deposited calcite has lower $\mathrm{Sr} / \mathrm{Ca}$ ratios than biogenic calcite precipitated under similar conditions (Katz et al., 1972; Baker et al., 1982), and thus, when biogenic calcite dissolves and reprecipitates, the $\mathrm{Sr}^{++}$content of the pore water increases (Matter et al., 1974; Gieskes, 1981). Hence, the extent of calcite dissolution and reprecipitation in foraminifer tests can be inferred from its assumed initial $\mathrm{Sr} / \mathrm{Ca}$ ratio, its present $\mathrm{Sr} / \mathrm{Ca}$ ratio, and the $\mathrm{Sr} / \mathrm{Ca}$ ratio of the inorganic calcite formed in equilibrium with the pore waters.
$\mathrm{Sr} / \mathrm{Ca}$ ratios of foraminifers from Holes 689B and 690C are listed in Table 3 and plotted in Figures 2A and 2B. Ratios for $A$. mayaroensis, G. multispinatus, A. australis, and N. truempyi from Hole $689 \mathrm{~B}$ range between 0.00087 and 0.00132 , while those for A. australis, A. mayaroensis, and $G$. beccariiformis from Hole $690 \mathrm{C}$ are between 0.00066 and 0.00210 . There are no data for monospecific Cretaceous foraminifers with which to compare these values. However, Delaney et al. (1985) reported $\mathrm{Sr} / \mathrm{Ca}$ ratios between 0.00188 and 0.0011 for Recent planktonic foraminifers growing at surface water temperatures between $10^{\circ}$ and $28^{\circ} \mathrm{C}$. Most of their values fall between 0.0014 and 0.0018 . Lower values of approximately 0.0010 were measured for the benthic taxon Uvigerina from core-top sediments. Likewise, most of the $\mathrm{Sr} / \mathrm{Ca}$ ratios reported by Lorens et al. (1977) for planktonic foraminifer species from core-top sediments fall between 0.0012 and 0.0016 .

$\mathrm{Sr}^{++}$concentrations at Holes $689 \mathrm{~B}$ and $690 \mathrm{C}$ increase almost linearly with depth from average seawater values of 0.09 mmol at the surface to $0.22 \mathrm{mmol}$ at $259 \mathrm{~m}$ and $0.159 \mathrm{mmol}$ at $296 \mathrm{~m}$, respectively (Egeberg et al., this volume, chapter 10). Replacement calcite precipitated in equilibrium with pore waters would have values close to 0.00057 at Hole 689B (Fig. 2A) and between 0.00050 and 0.00066 at Hole 690C (Fig. 2B) based on the distribution coefficient for $\mathrm{Sr}$ in Katz et al. (1972) for calcite precipitated from $0.1 \mathrm{mmol} \mathrm{Sr}^{++}$solutions and extrapolated to temperatures measured in these holes. $\mathrm{Sr} / \mathrm{Ca}$ ratios of foraminifers from Holes 689B and 690C are higher than those expected for diagenetically altered calcite, but slightly lower than those measured in Recent foraminifers. Hence, $\mathrm{Sr} / \mathrm{Ca}$ ratios do not indicate extensive replacement of the original foraminifer calcite by diagenetic calcite. Egeberg et al. (this volume, chapter 11) also concluded, based on $\mathrm{Sr}$ concentrations and ${ }^{87} \mathrm{Sr} /{ }^{86} \mathrm{Sr}$ ratios of both pore waters and bulk carbonate, that carbonate sediments at Holes 689B and 690C have not been affected by dissolution and reprecipitation processes.

\section{ISOTOPIC PRESERVATION}

Constancy of interspecific isotopic differences can be used as an indication of the preservation of original isotopic ratios of benthic foraminifers. Encrustation or replacement by secondary calcite can make the isotopic compositions of different species more similar to one another or increase their differences. When all taxa are altered simultaneously by similar processes, interspecific isotopic differences among species become smaller, disappearing as the amount of diagenetic calcite approaches $100 \%$. These differences may either increase or decrease when different species are encrusted or replaced to different extent.

Interspecific isotopic differences for Holes 689B and 690C are tabulated in Table 4. The similarity in mean $\delta^{13} \mathrm{C}$ and $\delta^{18} \mathrm{O}$ differences between $N$. truempyi and $G$. beccariiformis within and between sites suggests no diagenetic modification of the isotopic compositions of these taxa. However, mean $\delta^{18} \mathrm{O}$ differences between $G$. beccariiformis and $C$. incrassata from the two sites are approximately 1 per mil. The mean $\delta^{13} \mathrm{C}$ difference between $G$. beccariiformis and $C$. incrassata for the early Maestrichtian at Site 690 is also different from that of the same interval at Site 689, and that of the late Maestrichtian interval at Sites 689 and 690 . There is a large difference between late and early Maestrichtian mean $\delta^{18} \mathrm{O}$ and $\delta^{13} \mathrm{C}$ differences of $C$. incrassata minus $N$. truempyi (though this is based on comparison of only one early Maestrichtian sample). This evidence suggests the diagenetic alteration of $C$. incrassata Maestrichtian $\delta^{18} \mathrm{O}$ values and early Maestrichtian $\delta^{13} \mathrm{C}$ values at Site 690 . In view of that, we believe that paleoclimatic inferences based on the isotopic results of the other taxa are more reliable.

In summary, there appears to be no obvious modification of foraminifer original isotopic and elemental chemistries in concert with their microstructure alteration. The petrographic evi- 
Table 3. $\mathrm{Sr} / \mathrm{Ca}$ ratios of selected foraminifer species from Holes 689B and $690 \mathrm{C}$.

\begin{tabular}{|c|c|c|c|c|c|c|}
\hline $\begin{array}{l}\text { Core, section, } \\
\text { interval }(\mathrm{cm})\end{array}$ & $\begin{array}{l}\text { Depth } \\
\text { (mbsf) }\end{array}$ & $\begin{array}{c}\text { Gavelinella } \\
\text { beccariiformis }\end{array}$ & $\begin{array}{c}\text { Nuttallides } \\
\text { truempyi }\end{array}$ & $\begin{array}{c}\text { Abathomphalus } \\
\text { mayaroensis }\end{array}$ & $\begin{array}{l}\text { Globigerinelloides } \\
\text { multispinatus }\end{array}$ & $\begin{array}{c}\text { Archaeoglobigerina } \\
\text { australis }\end{array}$ \\
\hline \multicolumn{7}{|l|}{ Hole 689B } \\
\hline $27 \mathrm{X}-1,85-89$ & 246.87 & 1.1290 & & & & \\
\hline $27 X-3,83-87$ & 249.87 & 0.8722 & & 1.1180 & & \\
\hline $28 \mathrm{X}-1,76-80$ & 256.38 & 1.0040 & 0.8490 & 1.3250 & 1.2055 & \\
\hline $28 X-3,83-87$ & 259.45 & & & & & \\
\hline $28 X-4,83-87$ & 260.97 & 1.1462 & & & 0.9386 & \\
\hline $29 X-1,83-87$ & 266.05 & 1.2804 & & & 0.9386 & \\
\hline $29 X-2,83-87$ & 267.55 & 1.2395 & & & & \\
\hline $29 \mathrm{X}, \mathrm{CC}$ & 269.50 & 1.1794 & & & 1.1591 & \\
\hline $30 X-2,88-92$ & 277.30 & & & & & \\
\hline $30 X-3,78-83$ & 278.70 & 1.2800 & & & & \\
\hline \multicolumn{7}{|l|}{ Hole $690 \mathrm{C}$} \\
\hline $18 \mathrm{X}-1,119-123$ & 272.61 & 1.0180 & & & & 0.9613 \\
\hline $18 X-2,119-123$ & 273.91 & & 2.0980 & & & \\
\hline $18 X-3,98-102$ & 275.40 & 0.6567 & & 1.4480 & & 0.9364 \\
\hline $18 X-5,46-49$ & 277.87 & 0.9780 & & 1.7982 & 1.7982 & 1.2432 \\
\hline $19 \mathrm{X}-1,119-123$ & 282.31 & 1.2060 & & & & 1.1212 \\
\hline $19 \mathrm{X}-3,119-123$ & 285.31 & 1.3313 & & & & 1.3169 \\
\hline $19 X-5,110-112$ & 288.20 & 0.9565 & & & & 1.3476 \\
\hline $20 \mathrm{X}-1,118-121$ & 292.00 & 1.2305 & & & & 1.6314 \\
\hline $20 \mathrm{X}-3,116-118$ & 294.98 & 1.2010 & & & & 1.2347 \\
\hline $20 X-5,108-110$ & 297.82 & 1.1754 & & & & 1.4409 \\
\hline $20 \mathrm{X}, \mathrm{CC}$ & 300.40 & 0.9215 & & & & 1.1907 \\
\hline $21 X-3,118-122$ & 303.94 & 0.9136 & & & & 1.6107 \\
\hline $21 X-5,118-122$ & 306.94 & 1.2585 & & & & 1.3643 \\
\hline $22 \mathrm{X}-1,118-122$ & 311.62 & 1.4630 & & & & 1.0182 \\
\hline $22 \mathrm{X}-3,107-111$ & 314.52 & 1.4357 & & & & 1.0851 \\
\hline
\end{tabular}

Note: $\mathrm{Sr} / \mathrm{Ca}$ ratios are given as $1 \times 10^{-3}$ moles.
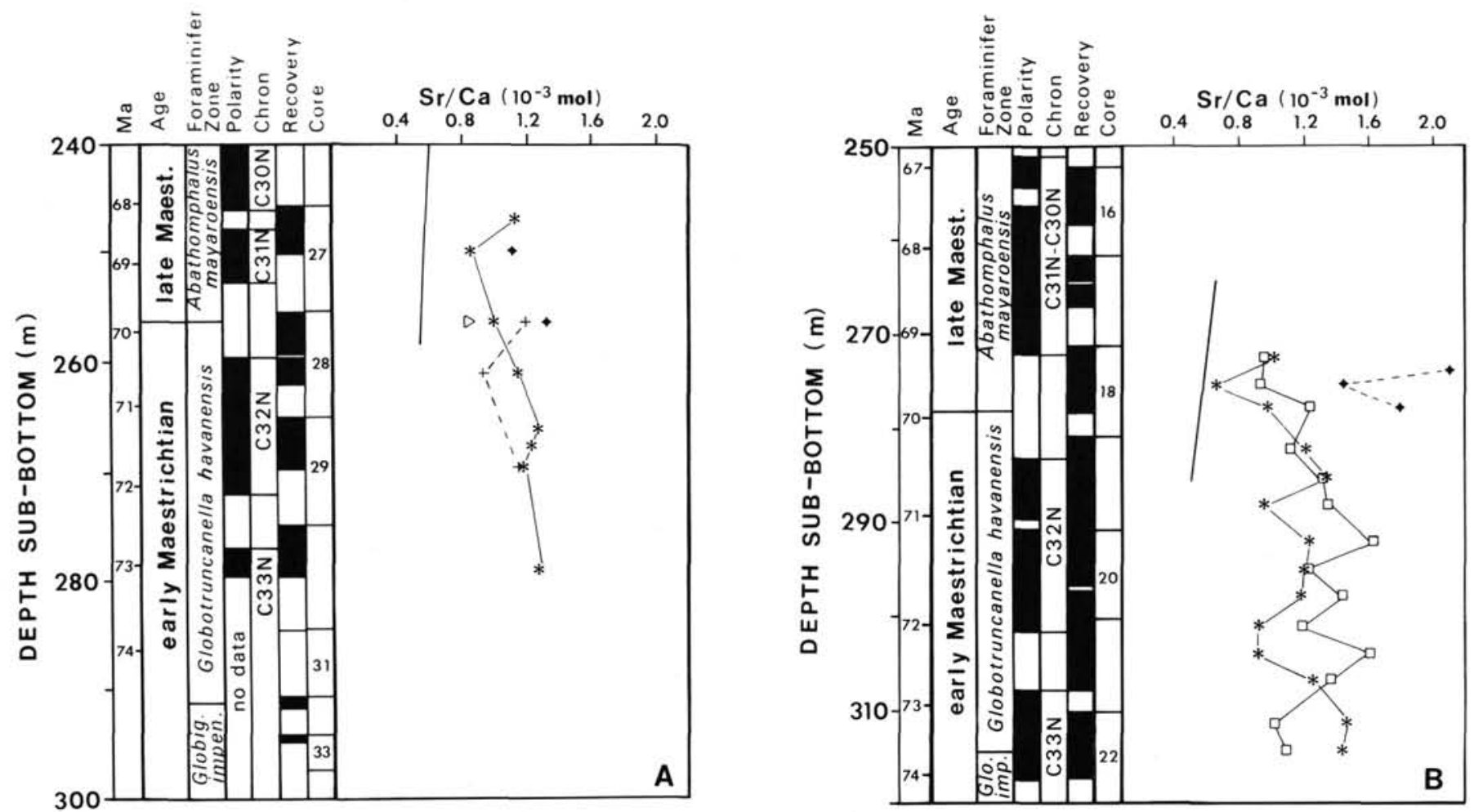

Figure 2. Sr/Ca ratios of selected foraminifer species. A. Hole 689B. B. Hole 690C. Open squares $=$ A. australis; crosses $=G$. multispinatus; solid diamonds $=A$. mayaroensis; asterisks $=G$. beccariiformis; right-pointing triangle $=N$. truempyi. The heavy solid line represents estimated $\mathrm{Sr} / \mathrm{Ca}$ ratios of calcite precipitated in equilibrium with pore water interpolated between pore-water measurements in Egeberg et al. (this volume, chapter 10). 
Table 4. Mean values of interspecific oxygen and carbon isotopic differences from Holes 689B and $690 \mathrm{C}$.

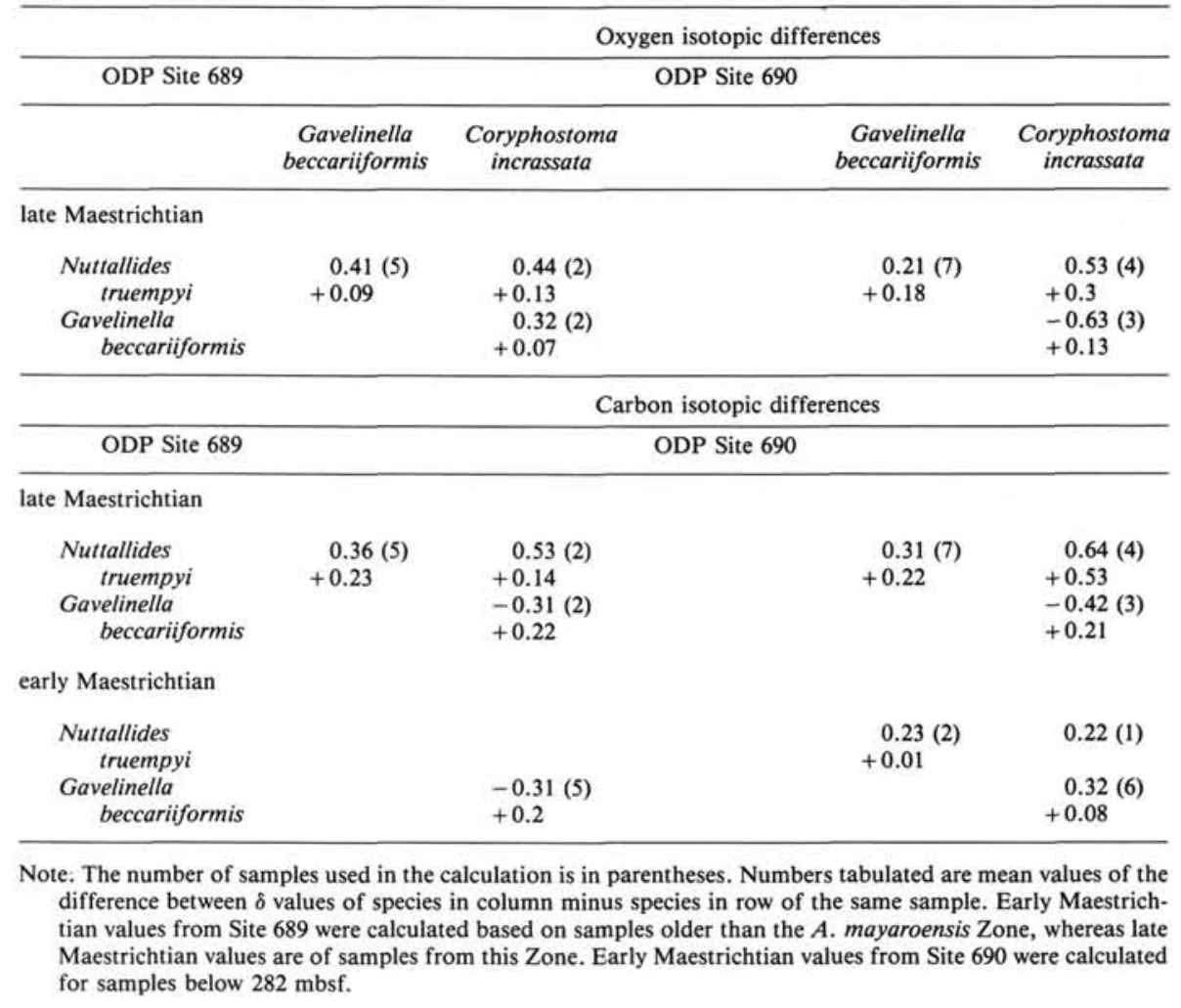

dence discussed above indicates that early Maestrichtian samples are texturally less altered than late Maestrichtian and earliest early Maestrichtian samples at both sites. Early Maestrichtian samples from Hole $690 \mathrm{C}$ are in general better preserved than those of analogous age from Hole 689B. If the extent of alteration of original isotopic signatures covaries with the extent of textural alteration, $\delta^{18} \mathrm{O}$ and $\delta^{13} \mathrm{C}$ interspecific differences in and between the two sites should have been modified accordingly. However, the isotopic data discussed above do not indicate this. Likewise, $\mathrm{Sr} / \mathrm{Ca}$ ratios of texturally poorly preserved foraminifer species are not consistently lower than those of texturally better preserved specimens. It appears that the processes responsible for modifying the original structure of the foraminifer wall did not significantly change the chemical and isotopic compositions of foraminifer calcite. One possibility is that test replacement has occurred in a closed system with little interaction with pore waters (Barrera and Savin, 1986; Barrera, 1987), where $\mathrm{Sr} / \mathrm{Ca},{ }^{18} \mathrm{O} /{ }^{16} \mathrm{O}$, and ${ }^{13} \mathrm{C} /{ }^{12} \mathrm{C}$ ratios of the precipitated calcite would be controlled by those of the dissolving calcite and $\mathrm{Sr} / \mathrm{Ca}$ ratios of pore waters will not be significantly changed.

\section{ISOTOPIC RESULTS}

The ${ }^{18} \mathrm{O} /{ }^{16} \mathrm{O}$ and ${ }^{13} \mathrm{C} /{ }^{12} \mathrm{C}$ ratios of foraminifers from Sites 689 and 690 are plotted in Figures 3 and 4 and listed in Tables 1 and 2 .

\section{Benthic Foraminifer Records}

The $\delta^{18} \mathrm{O}$ values of $G$. beccariiformis and $C$. incrassata show a distinctive trend of decreasing values with decreasing age in lower Maestrichtian sediments. The record from Site 690, which is more densely and more continuously sampled than that of the other site, indicates that the trend of $G$. beccariiformis $\delta^{18} \mathrm{O}$ val- ues probably begins with the highest values of the Maestrichtian at about $73 \mathrm{Ma}$ to $72 \mathrm{Ma}$ and is terminated by ${ }^{18} \mathrm{O}$ enrichment of approximately 0.3 per mil at about the time of the first appearance of Abathomphalus mayaroensis. Afterward, late Maestrichtian $\delta^{18} \mathrm{O}$ values of $G$. beccariiformis, $C$. incrassata, and Site $689 N$. truempyi show little change for the next $2.5 \mathrm{~m}$.y.

The $\delta^{13} \mathrm{C}$ values of the benthic foraminifer species fluctuate sympathetically at both sites. $\delta^{13} \mathrm{C}$ values were relatively high during a short interval in the earliest early Maestrichtian followed by lower values until prior to the beginning of the $\mathrm{A}$. $\mathrm{ma}$ yaroensis Zone. Higher benthic $\delta^{13} \mathrm{C}$ values, similar to those in the earliest early Maestrichtian, characterize this faunal zone. A distinctive feature of these records is a sharp decrease in $\delta^{13} \mathrm{C}$ values, which appears to have begun at about $72.2 \mathrm{Ma}$ and terminated at the onset of the late Maestrichtian. In the record from Site 690 , this ${ }^{13} \mathrm{C}$ excursion is immediately followed by the ${ }^{18} \mathrm{O}$ enrichment of $G$. beccariiformis discussed above.

Benthic foraminifer $\delta^{18} \mathrm{O}$ values from Site 689 are on the average higher than those from Site 690 , although sediments from the latter were deposited in shallower waters (Table 5). For example, mean average $\delta^{18} \mathrm{O}$ values of early Maestrichtian $G$. beccariiformis and late Maestrichtian N. truempyi from Site 689 are approximately 0.2 per mil higher than those from the same intervals at Site 690 . However, average $\delta^{18} \mathrm{O}$ values of late Maestrichtian $G$. beccariiformis and early Maestrichtian $C$. incrassata from Site 690 are not very different from those of their counterparts from Site 689 . Only the mean $\delta^{18} \mathrm{O}$ value of late Maestrichtian $C$. incrassata from Site 689 is lower than that from Site 690 . In contrast, mean $\delta^{13} \mathrm{C}$ values of benthic foraminifer taxa in each of the two Maestrichtian intervals at each site are very close, except for those of $C$. incrassata from the late Maestrichtian interval (Table 5). 
Table 5. Mean values of oxygen and carbon isotopic compositions of foraminifer species from Holes 689B and 690C.

\begin{tabular}{|c|c|c|c|c|c|c|c|c|c|c|c|c|}
\hline & \multicolumn{2}{|c|}{$\begin{array}{c}\text { Archeoglobigerina } \\
\text { australis }\end{array}$} & \multicolumn{2}{|c|}{$\begin{array}{c}\text { Globigerinelloides } \\
\text { multispinatus }\end{array}$} & \multicolumn{2}{|c|}{$\begin{array}{c}\text { Abathomphalus } \\
\text { mayaroensis }\end{array}$} & \multicolumn{2}{|c|}{$\begin{array}{c}\text { Nuttallides } \\
\text { truempyi }\end{array}$} & \multicolumn{2}{|c|}{$\begin{array}{c}\text { Gavelinella } \\
\text { beccariiformis }\end{array}$} & \multicolumn{2}{|c|}{$\begin{array}{c}\text { Coryphostoma } \\
\text { incrassata }\end{array}$} \\
\hline & $\delta^{18} O$ & $\delta^{13} \mathrm{C}$ & $\delta^{18} \mathrm{O}$ & $\delta^{13} \mathrm{C}$ & $\delta^{18} \mathrm{O}$ & $\delta^{13} \mathrm{C}$ & $\delta^{18} \mathrm{O}$ & $\delta^{13} \mathrm{C}$ & $\delta^{18} \mathrm{O}$ & $\overline{\delta^{13} \mathrm{C}}$ & $\delta^{18} \mathrm{O}$ & $\overline{\delta^{13} \mathrm{C}}$ \\
\hline \multicolumn{13}{|l|}{ Site 689} \\
\hline $\begin{array}{l}\text { late } \\
\text { Maestrichtian } \\
\text { early } \\
\quad \text { Maestrichtian }\end{array}$ & $\begin{array}{c}0.50 \\
(0.04) \\
-0.03 \\
(0.16)\end{array}$ & $\begin{array}{c}2.13 \\
(0.23) \\
1.92 \\
(0.36)\end{array}$ & $\begin{array}{c}0.52 \\
(0.30) \\
0.38 \\
(0.20)\end{array}$ & $\begin{array}{c}2.24 \\
(0.33) \\
1.85 \\
(0.43)\end{array}$ & $\begin{array}{c}0.50 \\
(0.18)\end{array}$ & $\begin{array}{c}2.26 \\
(1.39)\end{array}$ & $\begin{array}{c}1.11 \\
(0.08)\end{array}$ & $\begin{array}{c}1.45 \\
(0.41)\end{array}$ & $\begin{array}{c}0.70 \\
(0.11) \\
0.42 \\
(0.19)\end{array}$ & $\begin{array}{c}1.09 \\
(0.37) \\
0.88 \\
(0.33)\end{array}$ & $\begin{array}{c}0.93 \\
(0.02) \\
0.94 \\
(0.15)\end{array}$ & $\begin{array}{c}0.86 \\
(0.12) \\
0.41 \\
(0.37)\end{array}$ \\
\hline \multicolumn{13}{|l|}{ Site 690} \\
\hline $\begin{array}{l}\text { late } \\
\text { Maestrichtian } \\
\text { early } \\
\quad \text { Maestrichtian }\end{array}$ & $\begin{array}{c}0.26 \\
(0.27) \\
-0.52 \\
(0.30)\end{array}$ & $\begin{array}{c}2.38 \\
(0.29) \\
2.15 \\
(0.29)\end{array}$ & $\begin{array}{c}0.41 \\
(0.09) \\
0.07 \\
(0.22)\end{array}$ & $\begin{array}{c}2.63 \\
(0.60) \\
2.26 \\
(1.05)\end{array}$ & $\begin{array}{l}0.48 \\
(0.13)\end{array}$ & $\begin{array}{l}1.81 \\
(0.12)\end{array}$ & $\begin{array}{c}0.86 \\
(0.21) \\
0.65 \\
(0.14)\end{array}$ & $\begin{array}{c}1.35 \\
(0.40) \\
0.54 \\
(0.32)\end{array}$ & $\begin{array}{c}0.70 \\
(0.04) \\
0.23 \\
(0.17)\end{array}$ & $\begin{array}{c}1.02 \\
(0.36) \\
0.87 \\
(0.37)\end{array}$ & $\begin{array}{c}1.30 \\
(0.09) \\
0.92 \\
(0.21)\end{array}$ & $\begin{array}{c}1.43 \\
(0.10) \\
0.50 \\
(0.19)\end{array}$ \\
\hline
\end{tabular}

Note: Numbers tabulated are mean isotopic values and standard deviations (in parentheses). Mean isotopic values for the early Maestrichtian interval include all samples older than the first appearance of $A$. mayaroensis, whereas late Maestrichtian averages include only samples from the A. mayaroensis Zone.

\section{Surface Water Records}

Except for the significant high planktonic ratios in the earliest Maestrichtian (Figs. 3 and 4 ), $\delta^{18} \mathrm{O}$ values of $A$. australis increase with decreasing sediment age at both sites. This is similar to the trends observed in the benthic species' $\delta^{18} \mathrm{O}$ values. Bulk carbonate $\delta^{18} \mathrm{O}$ values at Site 690 also exhibit this general trend. At Site $690, \delta^{18} \mathrm{O}$ values of $G$. multispinatus increase in the earliest early Maestrichtian and remain high throughout the remain- der of the Maestrichtian. G. multispinatus and bulk carbonate $\delta^{18} \mathrm{O}$ values from Site 689 are variable but do not show a particular time trend.

The $\delta^{13} \mathrm{C}$ values of $A$. australis, $G$. multispinatus, and bulk carbonate exhibit somewhat similar trends at both sites. Sediments deposited during the latest early Maestrichtian were depleted in ${ }^{13} \mathrm{C}$ relative to older or younger Maestrichtian sediments. Planktonic foraminifer and bulk carbonate records from Site 690 fluctuate quasi-sympathetically with $\delta^{13} \mathrm{C}$ benthic records.

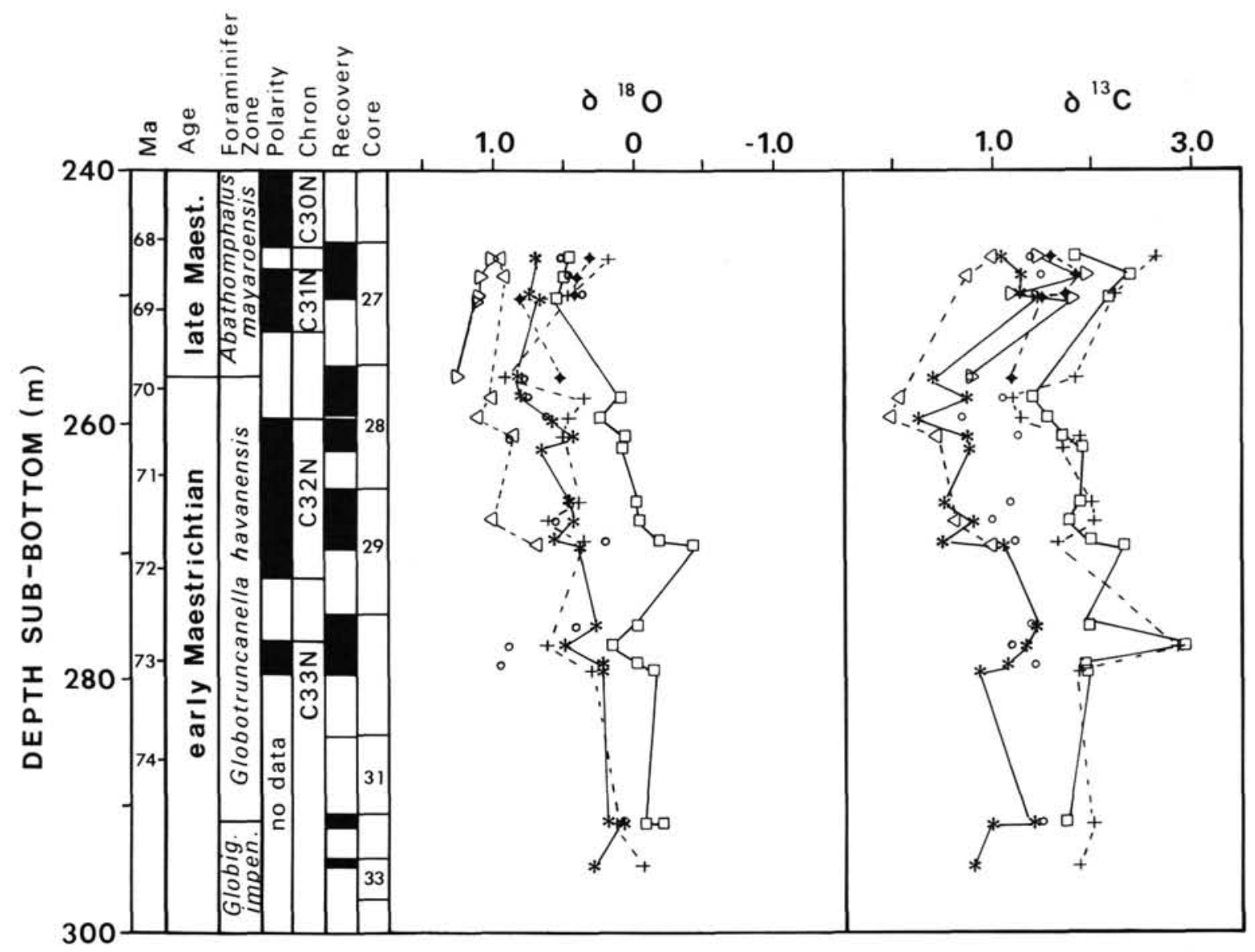

Figure $3 .{ }^{18} \mathrm{O} /{ }^{16} \mathrm{O}$ and ${ }^{13} \mathrm{C} /{ }^{12} \mathrm{C}$ ratios of selected foraminifer species from Hole 689B. Open squares = A. australis; crosses = G. beccariiformis; right-pointing triangles $=N$. truempyi; left-pointing triangles $=G$. incrassata; open circles $=$ bulk carbonate. 


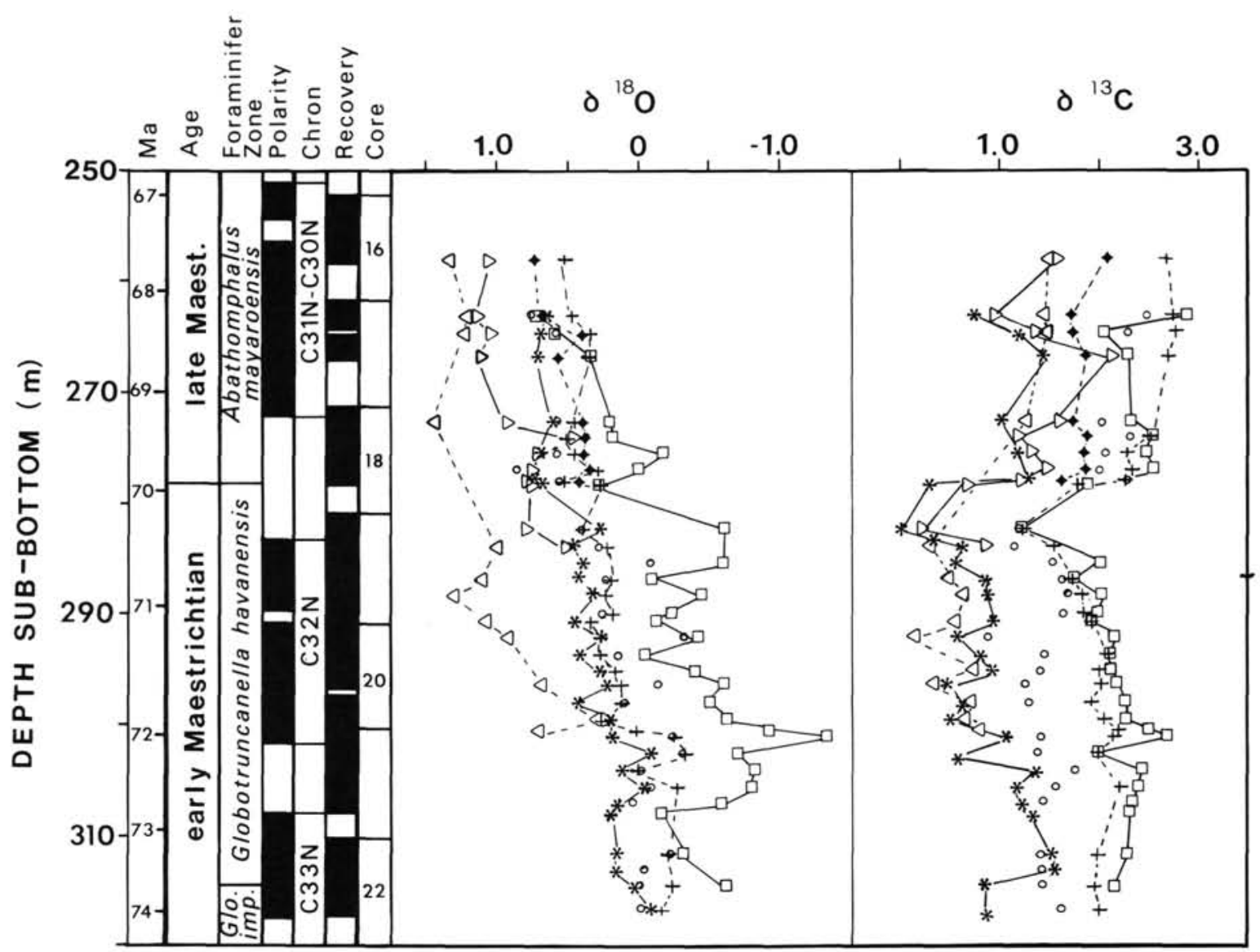

Figure $4 .{ }^{18} \mathrm{O} /{ }^{16} \mathrm{O}$ and ${ }^{13} \mathrm{C} /{ }^{12} \mathrm{C}$ ratios of selected foraminifer species from Hole $690 \mathrm{C}$. Symbols are the same as in Figure 3.

Mean $\delta^{18} \mathrm{O}$ and $\delta^{13} \mathrm{C}$ values of planktonic foraminifers calculated for the same Maestrichtian intervals at both sites (Table 5) indicate that Site 689 oxygen isotopic values are generally higher and carbon isotopic values are lower than at Site 690. Site 689 $\delta^{18} \mathrm{O}$ values of $G$. multispinatus are similar to those of the benthic foraminifer $G$. beccariiformis, whereas those from Site 690 are lower. Comparison of calculated mean $\delta^{18} \mathrm{O}$ values of planktonic foraminifers for the two sites suggests that the change between early Maestrichtian to late Maestrichtian time was greater at Site 690 than at Site 689. An analogous comparison of mean planktonic $\delta^{13} \mathrm{C}$ values suggests that the change from early Maestrichtian time to late Maestrichtian time was nearly equal at both sites.

\section{DEPTH STRATIFICATION OF PLANKTONIC SPECIES}

There is conflicting evidence regarding the depth habitat of Globigerinelloides species as inferred from $\delta^{18} \mathrm{O}$ values. Douglas and Savin (1978) concluded, based on analyses of tropical planktonic assemblages, that $G$. multispinatus had the lowest $\delta^{18} \mathrm{O}$ values and, thus, lived in the uppermost level of the water column. However, Boersma and Shackleton (1981) found that the depth ranking of species of Globigerinelloides was variable, which they attributed to either oxygen isotopic disequilibrium effects, diagenetic alteration of isotopic ratios, or size-dependent fractionation.

The $\delta^{18} \mathrm{O}$ records of the planktonic foraminifer species at Sites 689 and 690 suggest that $A$. australis was a shallow-dwelling species, whereas $G$. multispinatus and $A$. mayaroensis lived in deeper near-surface waters. The $\delta^{13} \mathrm{C}$ values of $A$. mayaroensis, a taxon which also inhabited intermediate to deep near-surface waters in low-latitude regions (Boersma and Shackleton, 1981), are lower than those of $G$. multispinatus and $A$. australis and are consistent with its inferred depth habitat in deeper waters. The $\delta^{13} \mathrm{C}$ record of $G$. multispinatus, considered to be a shallow-dwelling taxon in the low latitudes (Douglas and Savin, 1978), resembles that of $A$. australis at both sites. The predominance of $G$. multispinatus in shallow-water biofacies of Maestrichtian age on Seymour Island (Huber, 1988) also suggests a surface-water habitat in high-latitude regions. Therefore, we believe that $\delta^{18} \mathrm{O}$ values of $G$. multispinatus are probably affected by a vital effect and its $\delta^{13} \mathrm{C}$ record as that of $A$. australis reflects near-surface water conditions. The high variability in $A$. australis $\delta^{18} \mathrm{O}$ values is probably caused by other factors in addition to surface water temperatures.

\section{DISCUSSION}

Early isotopic paleoclimatic studies based on analysis of belemnite rostra from shallow-water sediments from Northern Russia (Teis et al., 1965; Naidin, 1966; and others), New Zealand (Stevens and Clayton, 1971), and Northern Europe (Lowenstam and Epstein, 1954; and others) revealed a Late Cretaceous cooling trend for high and subtropical latitude regions from a temperature maximum near the late Albian to a temperature minimum in the early Maestrichtian. Slightly higher temperatures were suggested for late Maestrichtian times. This general trend was later reproduced by the isotopic data of benthic and planktonic foraminifers and nannofossils from pelagic sedi- 
ments in the tropical Pacific Ocean (Douglas and Savin, 1975; Boersma and Shackleton, 1981), implying that the Late Cretaceous climatic cooling had been global.

The foraminifer isotopic data that have been published to date do not provide a consistent picture of the temperature evolution of surface and deep waters in the low and high latitudes during the Maestrichtian. This is probably due in part to several factors including: (1) the different stratigraphic ages of the samples; (2) the sample composition, which consists of single species and of mixtures of species with unknown isotopic fractionation; (3) modification of isotopic compositions of some samples by diagenetic alteration; and (4) the configuration of ocean basins and possible multiple sources of bottom waters in the Maestrichtian. For example, Douglas and Savin (1975) reported benthic foraminifer and nannofossil $\delta^{18} \mathrm{O}$ values from the Shatsky Rise in the Pacific Ocean that indicated a progressive decline in surface- and deep-water temperatures during the early Maestrichtian. Surface waters cooled while deep waters warmed in the late Maestrichtian. In contrast, Boersma and Shackleton's (1981) $\delta^{18} \mathrm{O}$ records for Site 465 , also in the tropical Pacific, show a sharp decline in deep-water temperatures in the earliest early Maestrichtian followed by higher temperatures through the remainder of the Maestrichtian. Near-surface waters at Site $\mathbf{4 6 5}$ warmed in the late Maestrichtian relative to early Maestrichtian temperatures. Benthic foraminifer $\delta^{18} \mathrm{O}$ records of sites in the South Atlantic are also difficult to interpret. Saito and van Donk (1974) reported $\delta^{18} \mathrm{O}$ values indicating cooling of deep and surface waters at Site 21 during the Maestrichtian. However, Maestrichtian $\delta^{18} \mathrm{O}$ values from Site 358 in the Argentine Basin decrease with sample age (Barrera and Savin, unpublished data, 1986).

The $\delta^{18} \mathrm{O}$ time curves of benthic and planktonic taxa from Sites 689 and 690 are consistent with time trends observed in the $\delta^{18} \mathrm{O}$ values of well-preserved benthic foraminifers from nearby Seymour Island in the Antarctic Peninsula (Barrera et al., 1987). The monospecific data from Seymour Island indicate warmer bottom shelf waters in the early Maestrichtian than in the late Campanian, a rapid drop in water temperatures during the transition from early to late Maestrichtian time, and lower water temperatures during the rest of the late Maestrichtian. Sites 689 and 690 oxygen isotope data likewise suggest a long-term cooling of surface and bottom waters in the southern South Atlantic during the Maestrichtian, punctuated by a sharp drop in temperatures at the onset of the late Maestrichtian (Figs. 3 and 4). This demonstrates that environmental conditions inferred from Seymour Island data were not caused solely by nearshore processes, but, indeed, represent climatic changes in the Antarctic oceans and continent at this time.

\section{INFERENCES ON THE ORIGIN OF BOTTOM WATERS IN THE SOUTHERN SOUTH ATLANTIC REGION}

Paleotemperature estimates based on mean ${ }^{18} \mathrm{O} /{ }^{16} \mathrm{O}$ ratios of G. beccariiformis (Table 5) for the early Maestrichtian interval suggest intermediate waters (at about the depth of $1500 \mathrm{~m}$ ) between about $11^{\circ}$ and $10^{\circ} \mathrm{C}$, whereas late Maestrichtian intermediate waters were closer to $9^{\circ} \mathrm{C}$ at the Maud Rise. Intermediate waters seem to have cooled by about $2^{\circ} \mathrm{C}$ from the early to late Maestrichtian. Seymour Island shelf bottom-water temperatures were estimated at between $5.5^{\circ}$ and $9^{\circ} \mathrm{C}$ in the early Maestrichtian and between $4^{\circ}$ and $8.5^{\circ} \mathrm{C}$ during late Maestrichtian, assuming seawater at this location had an average $\delta^{18} \mathrm{O}$ of -1.5 per mil relative to SMOW (Barrera et al., 1987). Even if the $\delta^{18} \mathrm{O}$ values of seawater at both locations were similar, intermediate waters at the Maud Rise sites were only slightly warmer than shelf waters on Seymour Island. These paleotemperature estimates for the Maud Rise and Seymour Island are compatible with the idea that the Antarctic margins were probable sites of bottom water production during the Maestrichtian as occurs today. Surface waters in Antarctic shelves could have become cold and dense enough to sink and become bottom waters, although sea-ice formation did not take place then as at present. It is also possible that bottom waters were formed from the sinking of warm, saline plumes in the low latitudes (Brass et al., 1982) and that they filled some ocean basins during the Maestrichtian. Nevertheless, bottom waters in the southern South Atlantic were likely of Antarctic origin. The oxygen isotopic compositions of benthic foraminifers from upper Maestrichtian sediments deposited at depths shallower than $2000 \mathrm{~m}$ in the South Atlantic indicate growth in waters of temperatures in the range of those estimated for the Maud Rise intermediate waters. Boersma (1984) estimated temperatures of $9^{\circ} \mathrm{C}$ for intermediate waters at the Agulhas Plateau during the latest Maestrichtian based on one measurement of $G$. beccariiformis. Shackleton et al. (1984) inferred latest Maestrichtian intermediate waters temperatures between about $6.5^{\circ}$ and $10^{\circ} \mathrm{C}$ based on benthic data from Sites 525 and 527 in the South Atlantic, adjusted for the isotopic fractionation of species (which renders the temperature estimates of Shackleton et al. slightly lower than those from the Maud Rise).

Higher oxygen isotopic ratios, in general, for Maestrichtian benthic foraminifer species at the shallower water depth Site 689 than those from the deeper water Site 690 (Table 5) do not necessarily indicate that the latter was bathed by warmer waters originating in a low-latitude location, as proposed for Paleogene sediments at this site (Kennett and Stott, this volume). Oxygen isotopic ratios of shallow-dwelling Maestrichtian planktonic foraminifers from Site 689 are also on the average higher than those from Site 690 , although we expect no significant differences between surface-water temperatures at these sites. We cannot offer an explanation for the higher oxygen isotope ratios of Site 689 foraminifers. However, carbon isotopic ratios of benthic foraminifer species from both sites are similar, suggesting that they were in contact with the same water mass. Hence, bottom water temperatures in the southern South Atlantic were likely lower than those of intermediate waters and perhaps more similar to those estimated at Seymour Island.

\section{INTERPRETATION OF CARBON ISOTOPE RATIOS}

Maestrichtian planktonic foraminifer $\delta^{13} \mathrm{C}$ values and time trends from the Maud Rise are typical of those observed in other deep-sea sites. Boersma (1984) reported that carbon isotope records of planktonic foraminifers from South and North Atlantic and Pacific deep-sea sites were very similar, exhibiting $\delta^{13} \mathrm{C}$ values around 2 per mil in lower Maestrichtian sediments and between 2.3 and 2.6 per mil in the A. mayaroensis Zone. Our values are in the range of those observed at these locations, and the magnitude of their increase from early to late Maestrichtian is also comparable (Figs. 3 and 4). Benthic foraminifer $\delta^{13} \mathrm{C}$ values, which fluctuate sympathetically with planktonic values, exhibit somewhat analogous time trends to that observed for Site $465 \delta^{13} \mathrm{C}$ values of Bulimina sp. (Boersma and Shackleton, 1981). At Sites 689 and 690, surface-to-bottom carbon isotope gradients remained more or less constant from early through late Maestrichtian time, with values between about 1 and 1.5 per mil. This indicates that the late Maestrichtian increase in $\delta^{13} \mathrm{C}$ was not entirely due to increased productivity in surface waters as proposed by Boersma (1984) but probably resulted from a global rise in sea level (Hallam, 1968) and increased storage of organic carbon in shallow shelf areas.

The Maud Rise depletion in ${ }^{13} \mathrm{C}$ of bicarbonate just prior to the earliest late Maestrichtian decline in water temperatures is observed in $\delta^{13} \mathrm{C}$ values of Seymour Island. Except for this feature, there is little resemblance between records at these loca- 
tions, probably because Seymour Island benthic foraminifer $\delta^{13} \mathrm{C}$ values were largely influenced by local environmental processes. This negative excursion is potentially a good stratigraphic marker because it appears to correlate with a drop in bulk carbonate $\delta^{13} \mathrm{C}$ values near the first appearance of $A$. mayaroensis in the sediments at Hole $700,13^{\circ}$ latitude to the north of the Maud Rise (Barrera and Huber, unpubl. data, 1988).

\section{SURFACE WATER TEMPERATURES AND PLANKTONIC FORAMINIFER PALEOBIOGEOGRAPHY}

The warmest episode of the Maestrichtian at the Maud Rise, as inferred from the oxygen isotope data from Site 690 , occurred between $73 \mathrm{Ma}$ and $72 \mathrm{Ma}$. Subsequently, both surface and intermediate waters cooled, but surface waters cooled sharply at about $69.9 \mathrm{Ma}$ and remained cool during the late Maestrichtian. A decrease in the thermal stratification of nearsurface waters after about $69.5 \mathrm{Ma}$ is inferred from the decrease in interspecific $\delta^{18} \mathrm{O}$ differences between planktonic taxa from Sites 689 and 690 (Table 5). Several keeled and nonkeeled species that previously were thought to have been restricted to warmer low-latitude regions have diachronous first appearances at the Maud Rise at about $71 \mathrm{Ma}, 70.5 \mathrm{Ma}, 69.5 \mathrm{Ma}$, and 66.5 Ma (Huber, this volume). However, oxygen isotope results presented in this study suggest progressive cooling of surface waters during this time interval. Periodic expansions of warm water masses into the south polar region have been proposed in paleobiogeographic models (e.g., Krasheninnikov and Basov, 1983) for the poleward migration of typical warm-water species. However, oxygen and carbon isotopic data from Holes 689B and 690C show no conspicuous shifts that can be correlated with these first appearance datums. Instead, the immigrant species thrived when fewer niches for thermophilic foraminifers appear to have been available. We suggest that the occurrences of these immigrant species at the Maud Rise were related neither to temperature nor to major water mass changes. Unfortunately, the causes of those seemingly anomalous occurrences cannot be discerned from the available geochemical data.

\section{ACKNOWLEDGMENTS}

The authors acknowledge the help of Linda Abel and Jennie Jackson (CWRU) and Scott Carpenter (UM) with the isotopic analyses. Samuel Savin (CWRU) and K. C. Lohmann (UM) provided the use of their facilities. An earlier version of this paper was greatly improved by the comments of two anonymous reviewers and Samuel Savin. The senior author is grateful to The Alfred Wegener Institut in Bremerhaven, Federal Republic of Germany, for the use of the scanning electron microscope. The authors thank James P. Kennett for making possible this work on sediments from Sites 689 and 690 and the Ocean Drilling Program for providing the samples. This research was supported by NSF grant OCE- 8800049 to the senior author.

\section{REFERENCES}

Askin, R. A., 1988. Campanian to Paleocene palynological succession of Seymour and adjacent islands, northeastern Antarctic Peninsula. In Feldmann, R. M., and Woodburne, M. O., (Eds.), Geology and Paleontology of Seymour Island, Antarctic Peninsula, Geol. Soc. Am., Mem. Ser., 169:131-153.

Axelrod, D. I., 1984. An interpretation of Cretaceous and Tertiary biota in polar regions. Palaeogeogr., Palaeoclimatol., Palaeoecol., 45: 105-147.

Baker, P. A., 1986. Interstitial water chemistry of DSDP Site 503 and its implications for submarine hydrothermal circulation. In Prell, W. L., Gardner, J. V., et al., Init. Repts. DSDP, 68: Washington (U.S. Govt. Printing Office), 467-474.
Baker, P. A., Gieskes, J. M., and Elderfield, H., 1982. Diagenesis of carbonate in deep-sea sediments-evidence from $\mathrm{Sr} / \mathrm{Ca}$ ratios and interstitial water dissolved Sr data. J. Sediment. Petrol., 52:71-82.

Barrera, E., 1987. Isotopic paleotemperatures, I. Effects of diagenesis, II. Late Cretaceous Temperatures [Ph.D. dissert.]. Case Western Reserve Univ., Cleveland.

Barrera, E., and Savin, S. M., 1986. Diagenesis of foraminiferal calcite in deep-sea sediments. Geol. Soc. Am. Abstr. Programs, 18(4):279 (Abstract).

Barrera, E., Huber, B. T., Savin, S. M., and Webb, P. N., 1987. Antarctic marine temperatures: late Campanian through early Paleocene. Paleoceanography, 2:21-47.

Belanger, P. E., Curry, W. B., and Matthews, R. K., 1981. Core-top evaluation of benthic foraminiferal isotopic ratios for paleoceanographic interpretations. Palaeogeogr., Palaeoclimatol., Palaeoecol., $33: 205-220$

Boersma, A., 1984. Campanian through Paleocene paleotemperatures and carbon isotope sequence and the Cretaceous-Tertiary boundary. In Berggren, W. A., and van Couvering, J. A. (Eds.), Catastrophes and Earth History, Princeton (Princeton Univ. Press), 247-277.

Boersma, A., and Shackleton, N. J., 1981. Oxygen and carbon isotope variations and planktonic foraminifer depth habitats, late Cretaceous to Paleocene, Central Pacific, Deep Sea Drilling Sites 463 and 465, In Thiede, J., Vallier, T. L., et al., Init. Repts. DSDP, 62: Washington (U.S. Govt. Printing Office), 513-526.

Brass, G. W., Southam, J. R., and Peterson, W. H., 1982. Warm saline bottom water in the ancient ocean. Nature, 296:620-632.

Buchardt, B., and Weiner, S., 1981. Diagenesis of aragonite from Upper Cretaceous ammonites: a geochemical case-study. Sedimentology, 28:423-438.

Craig, H., 1957. Isotopic standards for carbon and oxygen and corrections factors for mass spectrometric analysis of carbon dioxide. Geochim. Cosmochim. Acta, 12:133-149.

Creber, G. T., and Chaloner, W. G., 1985. Tree growth in the Mesozoic and early Tertiary and the reconstruction of paleoclimates. Palaeogeogr., Palaeoclimatol., Palaeoecol., 52:35-60.

Delaney, M. L., Be, A.W.H., and Boyle, E. A., 1985. Li, Sr, Mg, and $\mathrm{Na}$ in foraminiferal calcite shells from laboratory culture, sediment traps, and sediment cores. Geochim. Cosmochim. Acta, 49:13271341.

Douglas, R. G., and Savin, S. M., 1975. Oxygen and carbon isotope analyses of Tertiary and Cretaceous microfossils from Shatsky Rise and other sites in the North Pacific Ocean. In Larson, R. L., Moberly, R., et al., Init. Repts. DSDP, 32: Washington (U.S. Govt. Printing Office), 509-520.

1978. Oxygen isotopic evidence for the depth stratification of Tertiary and Cretaceous planktic foraminifera. Mar. Micropaleontol., 3:175-196.

Epstein, S., Buchsbaum, R., Lowenstam, H. A., and Urey, H. C., 1953. Revised carbonate-water isotopic temperature scale. Geol. Soc. Am. Bull., 64:1315-1326.

Gieskes, J. M., 1981. Deep sea drilling interstitial water studies: implications for chemical alteration of the oceanic crust, Layers I and II. In Warme, J. E., Douglas, R. G., and Winterer, E. L. (Eds.), The Deep Sea Drilling Project: A Decade of Progress, SEPM Spec. Publ., 32: 149-167.

Hallam, A., 1968. Major epeirogenic and eustatic changes since the Cretaceous, and their possible relationship to crustal structure. Am. J. Sci., 261:397-423.

Haq, B. U., Hardenbol, J., and Vail, P. R., 1987. The new chronostratigraphic basis of Cenozoic and Mesozoic sea level cycles. Cushman Found. Foram. Res., Spec. Publ., 24, Fig. 2.

Huber, B. T., 1988. Upper Campanian-Paleocene foraminifera from the James Ross Island region (Antarctic Peninsula). In Feldman, R. M., and Woodburne, M. O. (Eds.), Geology and Paleontology of Seymour Island, Antarctica. Geol. Soc. Am., Mem. Ser., 169:163-251.

Katz, A., Sass, E., Starinsky, A., and Holland, H. D., 1972. Strontium behavior in the aragonite-calcite transformation: an experimental study at $40-98^{\circ} \mathrm{C}$. Geochim. Cosmochim. Acta, 36:481-496.

Killingley, J. S., 1983. Effects of diagenetic recrystallization on ${ }^{18} \mathrm{O} /{ }^{16} \mathrm{O}$ values of deep-sea sediments. Nature, 301:594-597.

Krasheninnikov, V. A., and Basov, I. A., 1983. Stratigraphy of Cretaceous sediments of the Falkland Plateau based on planktonic fora- 
minifers, Deep Sea Drilling Project, Leg 71. In Ludwig, W. J., Krasheninnikov, V. A., et al., Init. Repts. DSDP, 71: Washington (U.S. Govt. Printing Office), 789-820.

Lawver, L. A., Sclater, J. G., and Meinke, L., 1985. Mesozoic and Cenozoic reconstructions of the South Atlantic. Tectonophysics, 114: 233-254.

Lorens, R. B., Williams, D. F., and Bender, M. L., 1977. The early nonstructural chemical diagenesis of foraminiferal calcite. J. Sediment. Petrol., 47:1602-1609.

Lowenstam, H., and Epstein, S., 1954. Paleotemperatures of post-Aptian Cretaceous as determined by the oxygen isotope method. $J$. Geol., 62:207-248.

Matter, A., Douglas, R. G., and Perch-Nielsen, K., 1974. Fossil preservation, geochemistry and diagenesis of carbonates from the Shatsky Rise, N. W. Pacific. In Larson, R. L., Moberly, R. L., et al., Init. Repts. DSDP, 32: Washington (U.S. Govt. Printing Office), 891921.

Naidin, D. P., 1966. Isotopic paleotemperatures of the Upper Cretaceous in the Russian Platform and other parts of the U.S.S.R. Geochim. Internat., 3:1038-1051.

Neugebauer, J., 1974. Some aspects of cementation in chalk. In Hsü, K. J., and Jenkins, H. C. (Eds.), Pelagic sediments on land and under the sea. Int. Assoc. Sedimentologists, Spec. Publ. 1:149-176. , 1975. Foraminiferen-Diagenese in der Schreibkreide. N. Jb. Geol. Palaont. Abh., 150:182-206.

Saito, T., and van Donk, J., 1974. Oxygen and carbon isotope measurements of Late Cretaceous and early Tertiary foraminifera. Micropaleontology, 20:152-177.

Savin, S. M., Keller, G., Killingley, J. S., Shaughnessy, L., Sommer, M. A., Vincent, E., and Woodruff, F., 1981. Miocene benthic foraminiferal isotope records: a synthesis. Mar. Micropaleontol., 6:423450.

Shackleton, N., Hall, M. A., and Boersma, A., 1984. Oxygen and carbon isotope data from Leg 74 foraminifera. In Moore, T. C., Rabi- nowitz, P.D., et al., Init. Repts. DSDP, 74: Washington (U.S. Govt. Printing Office), 599-612.

Stevens, G. R., and Clayton, R. N., 1971. Oxygen isotope studies on Jurassic and Cretaceous belemnites from New Zealand and their biogeographic significance. J. Geol. Geophys., 14:829-897.

Stout, P. M., 1985. Chemical diagenesis of pelagic biogenic sediments from the equatorial Pacific [Ph.D. dissert.]. Univ. California, San Diego.

Teis, R. V., Naidin, D. P., and Zadorozhny, I. K., 1965. Determination of Upper Cretaceous temperatures on the Russian platform and some other regions, from the oxygen isotope composition of organic calcite. Problemy Geokhmii, 648-660.

Towe, K. M., and Cifelli, R., 1967. Wall structure in the calcareous foraminifera: crystallographic aspects and a model for calcification. $J$. Paleontol., 41:742-762.

Vergnaud Grazzini, C., 1976. Non-equilibrium isotopic compositions of shells of planktonic foraminifera in the Mediterranean Sea. Palaeogeogr., Palaeoclimatol., Palaeoecol., 20:263-276.

Williams, D. F., Sommer, M. A., and Bender, M. L., 1977. Carbon isotopic composition of recent planktonic foraminifera of the Indian Ocean. Earth Planet. Sci. Lett., 36:391-403.

Williams, D. F., Be, A. W. H., and Fairbanks, R. G., 1979. Seasonal oxygen isotopic variations in living planktonic foraminifera off Bermuda. Science, 206:447-449.

Woodruff, F., Savin, S. M., and Douglas, R. G., 1980. Biological fractionation of oxygen and carbon isotopes by Recent benthic foraminifera. Mar. Micropaleontol., 5:3-11.

Date of initial receipt: 28 February 1989

Date of acceptance: 16 October 1989

Ms 113B-137 


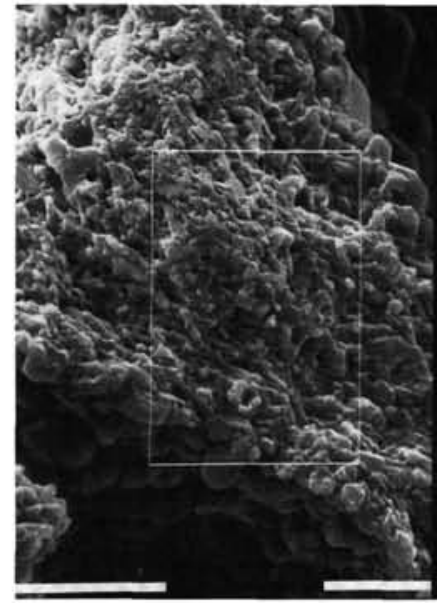

1

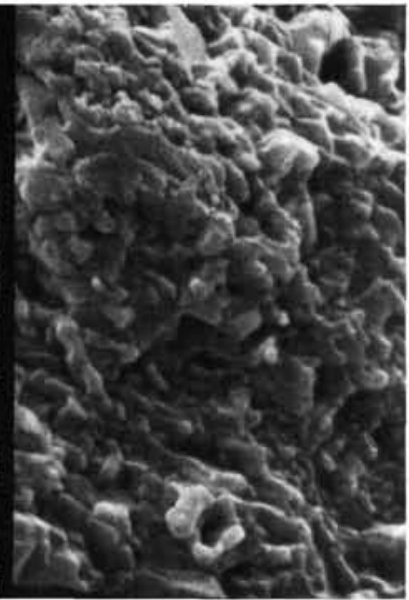

$5 \mu \mathrm{m}$

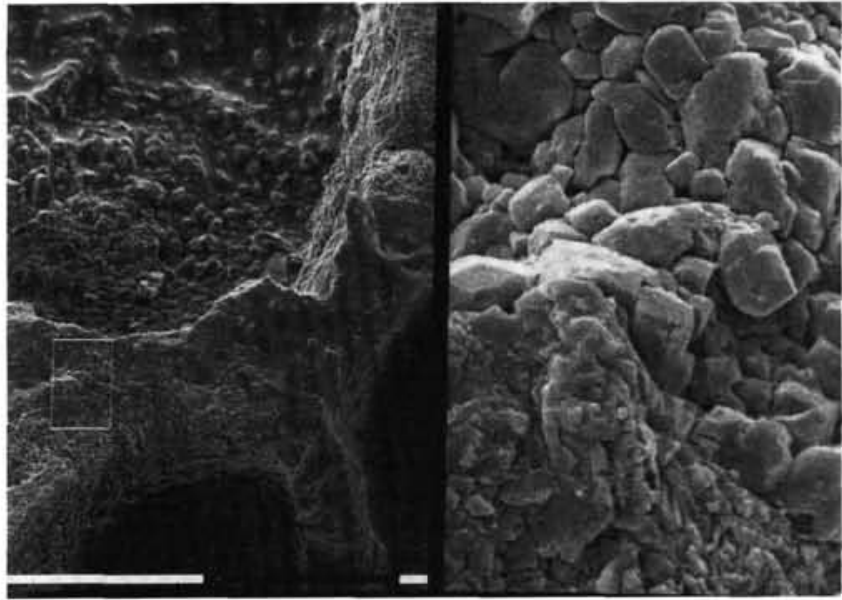

2 $50 \mu \mathrm{m}$
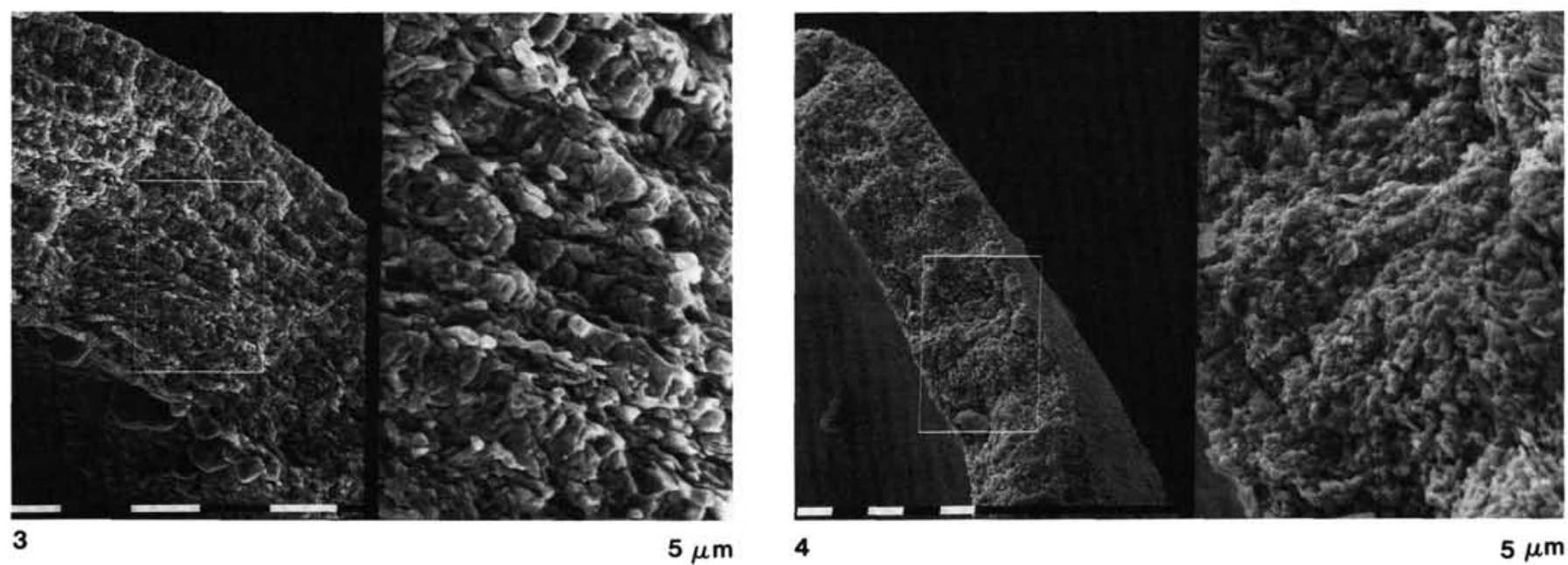

Plate 1. 1. Fractured test of $N$. truempyi showing a septal wall composed of coarse crystal of replacement calcite. The photograph in the right shows the area enclosed by the rectangle on the left. Interior surface chambers are covered by euhedral diagenetic calcite. Sample 113-690C-17X-1, 119-123 $\mathrm{cm}$. 2. Septal wall of $G$. beccariiformis composed in part of large euhedral crystals (indicated by arrow) and of blocky secondary calcite. Sample $113-690 \mathrm{C}-17 \mathrm{X}-3,119-123 \mathrm{~cm}$. 3. Wall structure of $G$. beccariiformis replaced by coarse secondary calcite. Note large euhedral overgrowth calcite crystals on the interior surface of the chambers, indicated by arrow. Sample 113-690C-19X-1, 119-123 cm. 4. Wall structure of a well-preserved specimen of $G$. beccariiformis composed of fine-grained calcite. Interior surface chambers are free of overgrowth calcite. Sample 113-690C-19X-3, $119-123 \mathrm{~cm}$. 


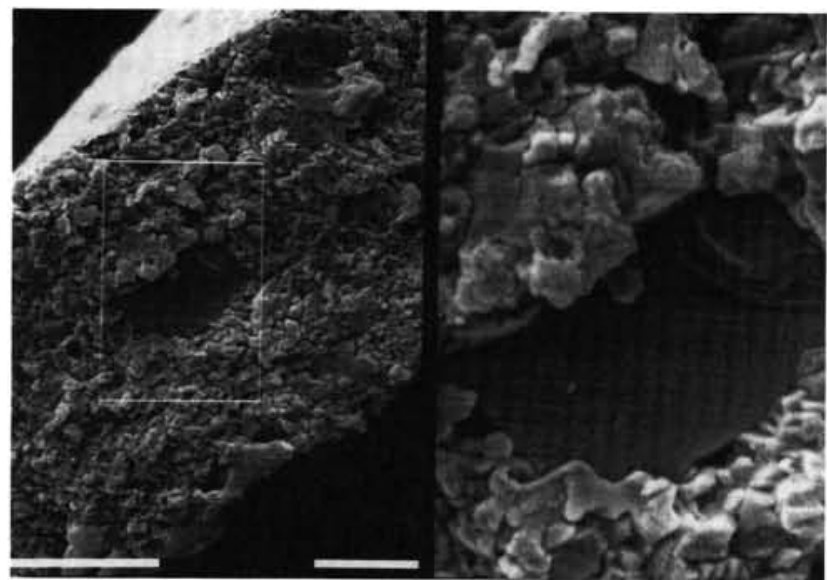

1

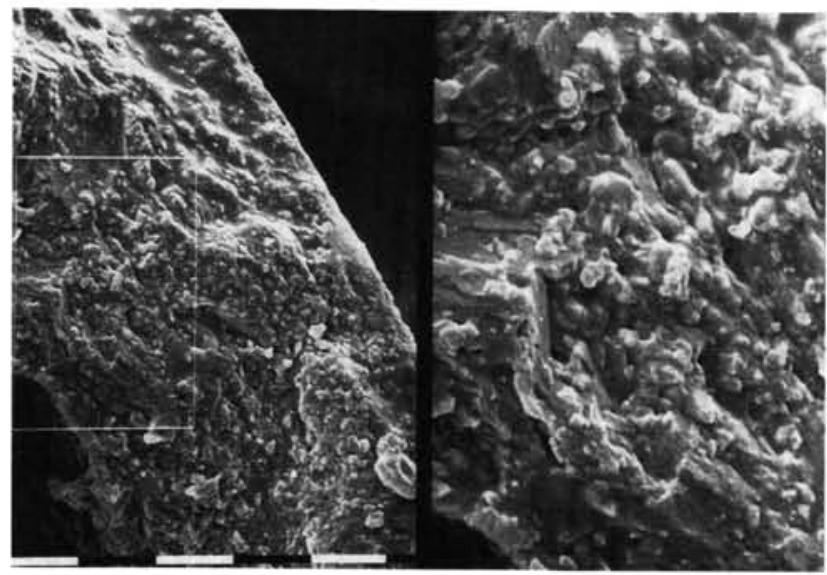

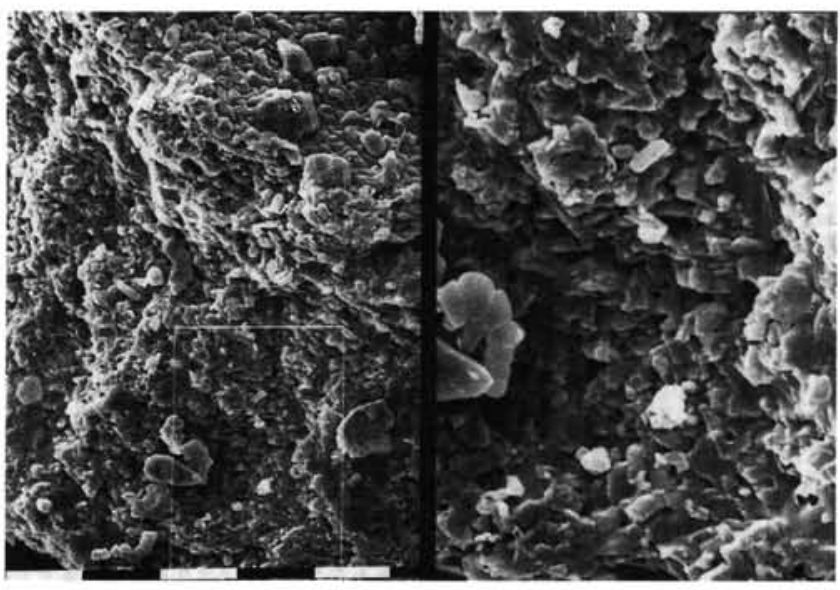

2

$5 \mu \mathrm{m}$

Plate 2. 1. Aspect of the chamber wall of $G$. beccariiformis showing a large block of secondary calcite. Sample 113-690C-21X-1, 118-122 cm. 2. Blocky diagenetic texture (indicated by arrow) in the chamber wall of a $G$. beccariiformis specimen. Round holes distributed throughout the wall of this specimen (more apparent in lower right-side of the photograph) are microbial tubes (Claude Monty, pers. comm., 1988). Sample 113-689B-27X$1,85-89 \mathrm{~cm}$. 3. Chamber wall of $G$. beccariiformis replaced by blocky calcite (fracture surfaces are shown by arrow). Sample 113-689B-32X, CC. 4. Chamber wall of $C$. incrassata replaced by blocky calcite. Sample 113-690C-19X-1, 119-123 cm. 


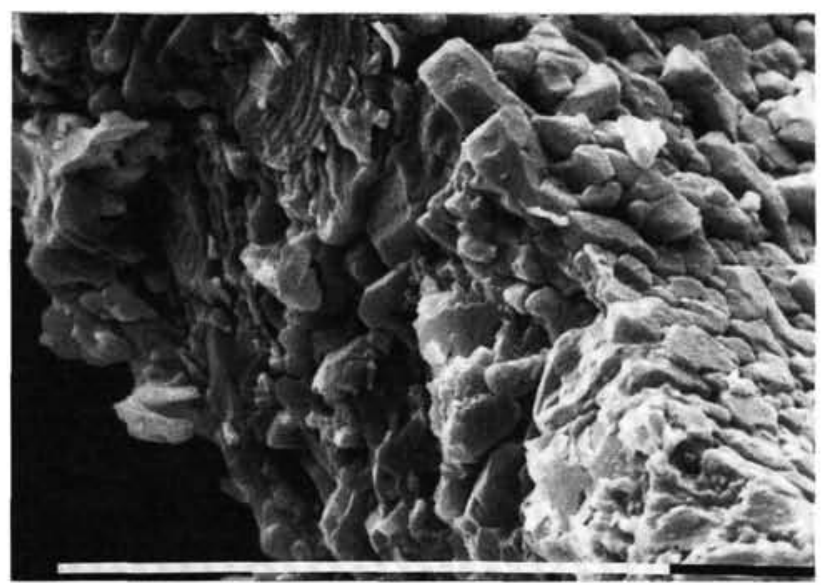

1

$10 \mu \mathrm{m}$

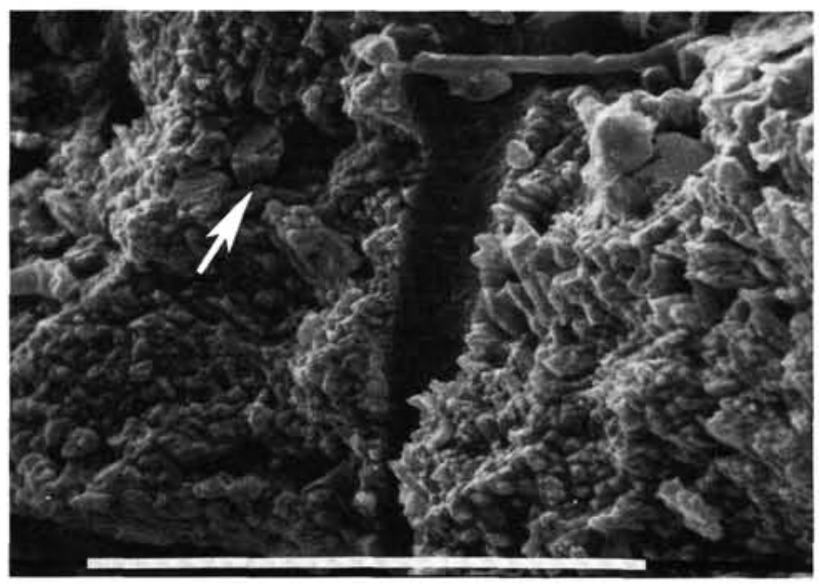

3

$10 \mu \mathrm{m}$

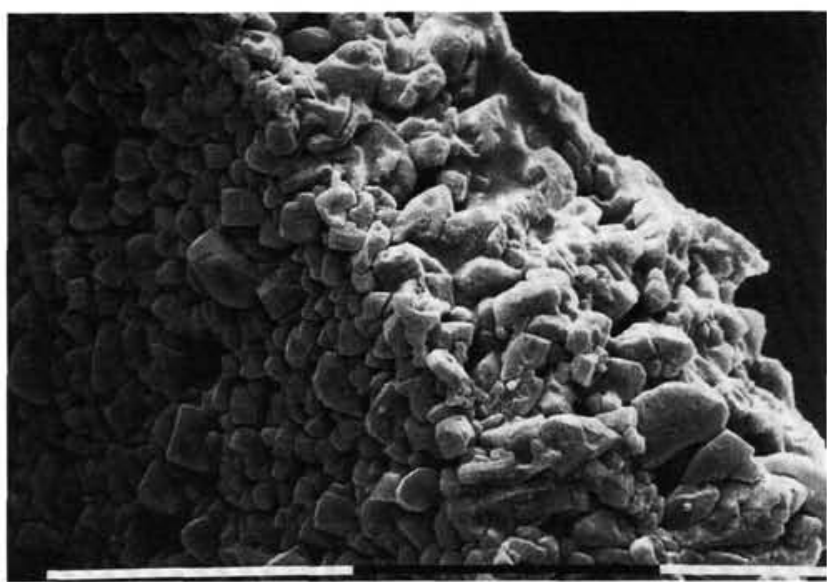

2

$10 \mu \mathrm{m}$

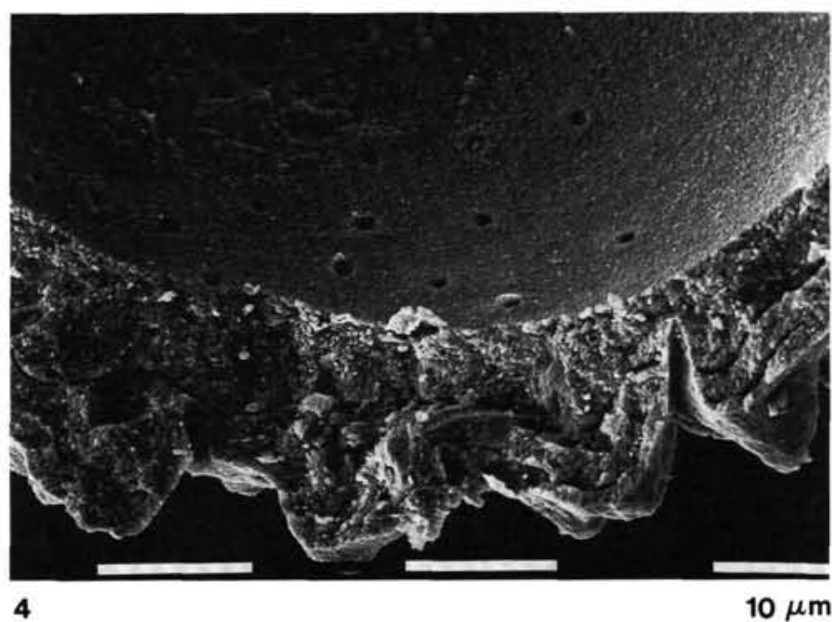

Plate 3. 1. Wall structure of $C$. incrassata composed of large euhedral crystals of secondary calcite. Sample 113-689B-27X-2, 83-87 cm. 2. Exterior chamber wall of $A$. mayaroensis entirely composed of large euhedral secondary calcite. Interior surface chambers are overgrown with diagenetic calcite. Sample 113-689B-27X-2, 83-87 cm. 3. Chamber wall of A. australis with patches of fine-grained calcite and coarse-grained diagenetic calcite (shown by arrow) in what appears to be solution cavities. Pore surfaces are free of large overgrowth calcite. Sample 113-690C-19X-1, 119-123 $\mathrm{cm}$. 4. Specimen of $A$. australis exhibiting apparent excellent preservation. Notice boundaries between layers of the wall structure and interior surface free of overgrowth calcite. Sample 113-690C-20X-3, 116-118 cm. 


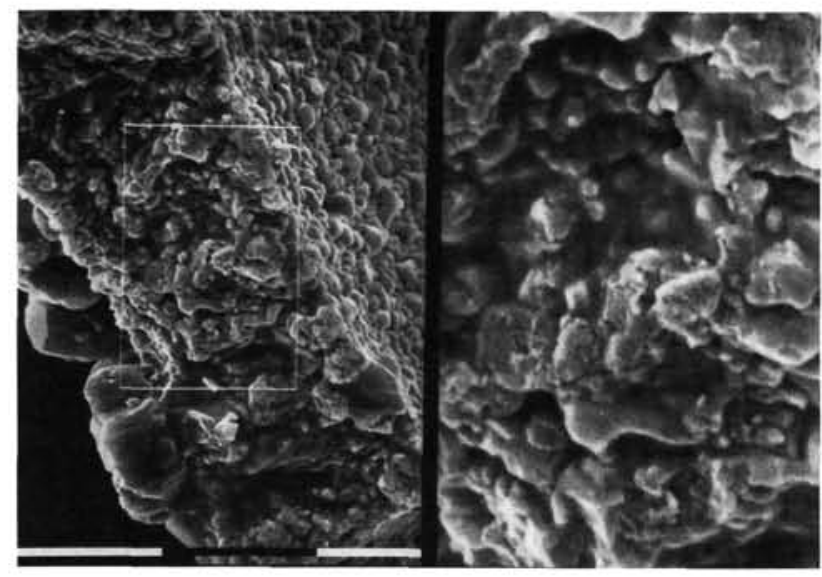

1

$5 \mu \mathrm{m}$

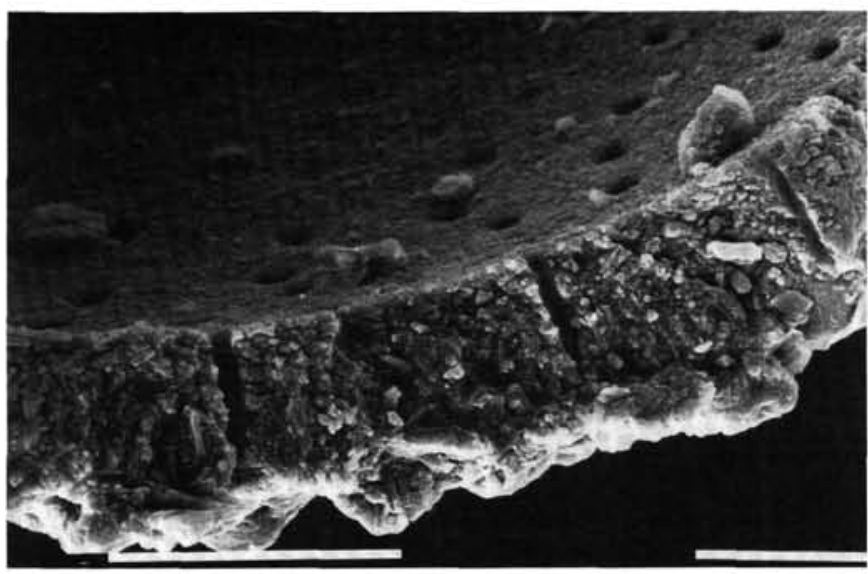

2

$10 \mu \mathrm{m}$

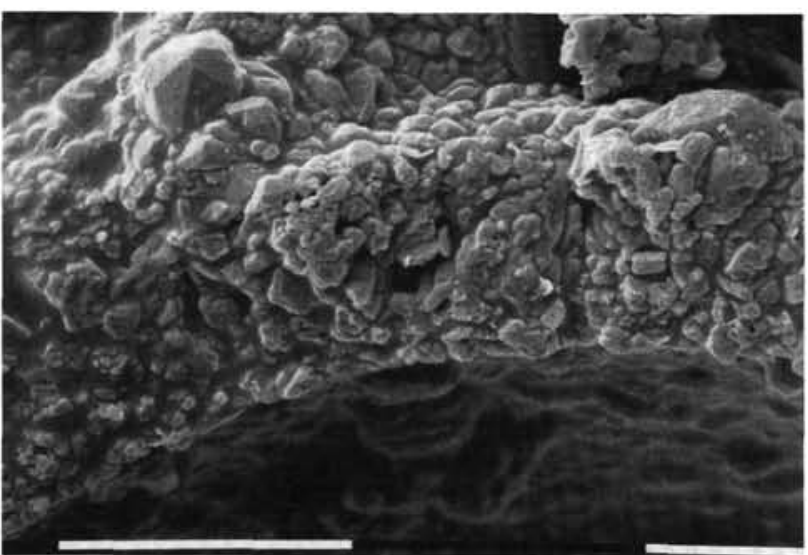

3

$10 \mu \mathrm{m}$

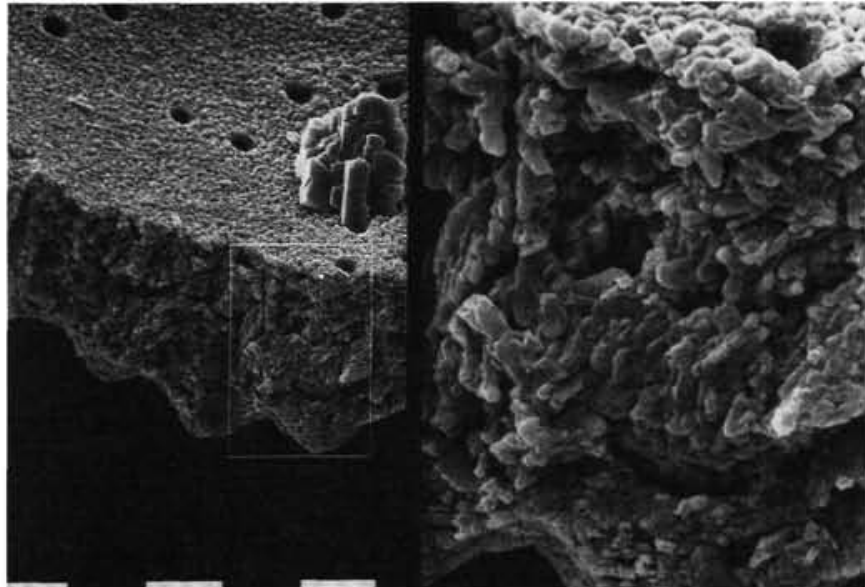

$5 \mu \mathrm{m}$

Plate 4. 1. Exterior chamber wall of $A$. australis characterized by a diagenetic texture somewhat similar to the blocky texture seen in benthic foraminifer specimens. Sample 113-689B-32X, CC. 2. Chamber wall of $G$. multispinatus showing very good preservation and no apparent replacement by secondary calcite. Interior surface chambers are also free of large overgrowth calcite crystals. Sample $113-690 \mathrm{C}-20 \mathrm{X}-3,116-118 \mathrm{~cm}$. 3. Wall of an early chamber $G$. multispinatus replaced by coarse-grained diagenetic calcite. Sample 113-689B-28X-2, 80-84 cm. 4. Chamber wall of a $G$. multispinatus specimen affected by calcite replacement and solution. Sample 113-689B-28X, CC. 